\title{
Something Scary is Out There Il: the Interplay of Childhood Experiences, Relict Sexual Dinichism, and Cross-cultural Differences in Spatial Fears
}

\author{
Richard G. Coss $^{1} \mathbb{D}$. Shelley A. Blozis ${ }^{1}$
}

Received: 1 March 2021 / Revised: 30 May 2021 / Accepted: 4 June 2021 / Published online: 1 July 2021

(c) The Author(s) 2021

\begin{abstract}
Children's nighttime fear is hypothesized as a cognitive relict reflecting a long history of natural selection for anticipating the direction of nighttime predatory attacks on the presumed human ancestor, Australopithecus afarensis, whose small-bodied females nesting in trees would have anticipated predatory attacks from below. Heavier males nesting on the ground would have anticipated nighttime predatory attacks from their sides. Previous research on preschool children and adults supports this cognitive-relict hypothesis by showing developmental consistencies in their remembrances of the location of a "scary thing" relative to their beds. The current study expands this research by investigating whether nighttime fear in childhood, including the effect of parental threats to behave, influenced adult spatial fears in different biotic and abiotic situations. A 25-item questionnaire employing ordinal scales was given to 474 foreign-born Vietnamese and ethnic Chinese adults living in the USA. Univariate analyses of adult remembrances of childhood indicated that females were more fearful of something scary below their beds than males. To examine the influence of childhood nighttime fear on adult fears, exploratory factor analyses supported three factors: (1) indeterminate agents, indicated something scary under the bed, the difficulty locating unspecific threats, and the brief appearances of large apparitions; (2) environmental uncertainty, indicated by potential encounters with unseen animate threats; (3) predictable animals, as the relative comfort of viewing animals in zoo exhibits. Using structural equation modeling, the results suggest that childhood nighttime fear influenced only the latent variable, indeterminate agents, in both groups via the mediating variable, parental threats.
\end{abstract}

Keywords Adult spatial fears $\cdot$ Chinese $\cdot$ Cross-cultural survey $\cdot$ Children's nighttime fear $\cdot$ Parental threat $\cdot$ Sexual dinichism · Vietnamese

\section{Introduction}

\section{I'm Not Afraid of the Dark. I'm Afraid of what's in the Dark!}

Caption: "Dennis the Menace" by cartoonist Hank Ketcham, 1989, Hearst Communications.

Normal fear is defined as a reaction to real or imagined threats, often originating in childhood (Morris \& Kratochwill, 1983; King et al., 1988). The expression of fears in specific contexts has been investigated extensively for more than a

Richard G. Coss

rgcoss@ucdavis.edu

1 Department of Psychology, University of California, Davis, CA, USA century (e.g., Hall, 1897) and includes reports of sex and country differences (reviewed by Gullone, 2000). Several researchers have suggested that some patterns of fearfulness involving simple phobias might have an evolutionary origin (e.g., Davey, 1995; Öhman, 1986), whereas others have emphasized the role of individual experiences (Morris \& Kratochwill, 1983; King et al., 1988). The focus of the current study is to explore sex and cross-cultural differences in the pattern of fearfulness using evolutionary, developmental, and cross-cultural perspectives to test hypotheses explaining how certain fears are acquired. We will summarize our findings in the context of how anticipated or imagined threats play an important role in the cross-cultural narratives of evil spirits, reflected in contemporary literature and cinema.

Before turning to our study, we first review the literature on evolutionary and cultural influences on fear acquisition. Then, we argue that the association between fear and 
supernatural entities may have an evolutionary origin in that the predators threatening to early hominins were analogous to things contextually integrated with nighttime darkness. This view is similar to the speculations proffered by Atran (2002). We finish our introduction with our rationale for the selection of ethnic groups and hypotheses for our study.

\section{Evolutionary Hypotheses for Sex Differences in the Development of Specific Fears}

There are three hypotheses for how natural selection might have shaped the evolution of sex differences in specific fears. The first hypothesis, preparedness, initially proffered by Seligman (1970, 1971; see also Darwin, 1877), and extended more explicitly to phobias (Marks \& Tobena, 1990), considers that humans and other species currently exhibit differential learning capabilities in acquiring fears that reflect historically important organism-environment relationships, as well as the absence of specific relationships (for a critique of the logical fallacy of the preparedness construct, see Rutter \& Garmezy, 1983, p. 807; Arrindell et al., 1991, p. 120). Such innate specialization for appraising some threats appropriately, but not others, would require consistent circumstances in which failure to learn about specific hazards would constitute the sources of natural selection, both removing individuals from the gene pool and fostering the spread of successful learning behaviors. Kirkpatrick (1984) suggests that this preparedness construct can explain some sex differences in the development of specific fears, such as the greater fear of certain animals by females. Although not directly focusing on fear, Kimura (1996) presents the argument that ancestral males and females engaged in a division of labor in which males hunted and females gathered resources, requiring different tactics in spatial navigation and vigilance (also see Silverman \& Eals, 1992; Silverman et al., 2007). Such a sex difference in visually mediated spatial behavior might engender between males and females different patterns of fearfulness associated with some environmental hazards. However, Late-Pleistocene burial practices suggest that females also hunted big game (Haas et al., 2020), so this assumption of a consistence sexual division of labor is tenuous. Finally, Susman et al. (1984) developed the construct of sexual dinichism (i.e., niche partitioning) to describe how sexual-size dimorphism in the body size and morphology of the Middle-Pliocene hominin, Australopithecus afarensis, restricted habitat use in East Africa more than 3 million years ago. Au. afarensis is generally considered to be the direct ancestor of the genus Homo (McHenry, 1992; Lockwood et al., 1996; Plavcan et al., 2005; Villmoare et al., 2015; Masao et al., 2016), and Au. afarensis males appeared to have been much heavier than females, approaching the sexual-size dimorphism ratio of gorillas (McHenry, 1992; Scott \& Stroik, 2006; Gordon et al., 2008; Grabowski et al., 2015; Masao et al., 2016; for a critique, see Reno et al., 2003, Reno \& Lovejoy, 2015).

Reviewed by Coss (2021), the sexual dinichism construct was developed from insights derived from the fossil record of $A u$. afarensis, in which smaller-bodied females were thought to be more capable of using trees effectively for foraging and nest building than were much heavier males. Much like the hunter-gatherer model that posits sex differences in habitat use (Silverman et al., 2007), differences in sexual-size dimorphism placed constraints on habitat use by each sex, especially the energetic cost to females of traveling long distances on the ground (Jungers, 1982) and branch breaking by heavier males foraging in trees (for evidence of a female $A u$. afarensis falling from a tall tree, see Kappelman et al., 2016).

Behavioral relicts of hypothesized $A u$. afarensis sexual dinichism might still persist in modern humans not unlike the evolutionary persistence of antipredator behavior in some species under prolonged relaxed natural selection. For example, innate recognition of predatory threats has been documented in developmental studies of animal behavior that also include predator-naïve prey living for thousands of years without contact with former predators (e.g., Blumstein, 2002; Coss, 1991, 1999; Li et al., 2011). Recognition of former snake predators can persist in several populations of California ground squirrels (Otospermophilus beecheyi) for more than 300,000 years of relaxed selection (Coss, 1991, 1999); albeit, the time frame for recognition-system disintegration is unknown for this species. Ancestral snake recognition is not evident in Arctic ground squirrels (Spermophilus parryii) whose ancestors have been free of snake predation for more than 3 million years (Goldthwaite et al., 1990). However, the rate of disintegration of evolved predator-recognition systems is affected by species generation times that control the introduction of disruptive mutations with loss-of-function (see Lahti et al., 2009; McLean et al., 2011; Deacon, 2016; Evans et al., 2019). When the 300,000-year time frame of relaxed selection for snake recognition influenced by a ground squirrel generation time of 1 to 2 years is scaled to the 29-year generation time estimated for humans (see Langergraber et al., 2012, p. 15,717), it is not unreasonable to propose that sex differences in arboreal-related behavior might still persist in young children from the Middle-Pliocene age of Au. afarensis.

Common chimpanzees (Pan troglodytes) and bonobos ( $P$. paniscus) also show some behavioral evidence of a long history of sexual-size dimorphism with females using trees for a broader range of activities than do males (Doran, 1993; Doran \& Hunt, 1994), including building nests much higher in trees than males (Fruth \& Hohmann, 1994). Such sex differences in habitat use likely preceded the divergence of chimpanzees and humans 7 to 8 million years ago (Ma) based on molecular clock estimates (Langergraber et al., 
2012), but see Moorjani et al. (2016) for a 12-Ma divergence estimate), and it must be noted that chimpanzees and bonobos have less sexual-size dimorphism than that estimated for Au. afarensis.

More specifically relevant to the aforementioned findings about the ways children incorporate spatial information in evaluating fearful situations, there is clear evidence that baboons, macaques, and langurs seem to anticipate predatory attacks at night, and these primates select sleeping trees that afford a nighttime defense. Behaviors showing anticipation of the direction of nighttime predatory attacks from below includes selecting sleeping sites that are close to the margins of crown canopies because the thinner branches near the crown edges restrict access by heavier leopards and pythons (Ramakrishnan \& Coss, 2000, 2001). Similarly defensive, bonobos build night nests high in the trees to prevent leopard attacks (Fruth \& Hohmann, 1994).

In an explicit test of the sexual-dinichism hypothesis, Coss and Moore (2002) examined the fearful attributions of preschool children toward the use of trees as refuge sites in a simulated antipredator context. In this investigation, 3and 4-year-old American girls were more cognizant of the utility of using thinner branches to avoid a heavy-bodied predator than were same-age boys. The presence of historical sexual-size dinichism also appears to be manifested in non-fearful situations with arboreal properties. For example, girls are observed to climb playground structures to a greater extent than do boys (Halliday \& McNaughton, 1982; Coss $\&$ Goldthwaite, 1995) and, in beginning rock climbers, girls exhibit more advanced climbing skills than do boys (Testa \& Debû, 1997). In contrast with these findings, men rather than women in preliterate societies typically climb trees for procuring resources (Kraft et al., 2014). Nevertheless, a seminatural simulation of antipredator behavior on a playground yielded additional results consistent with the sexual-dinichism hypothesis. In this study, a reliably greater frequency of preschool girls selected exposed playground areas where they could monitor a model leopard unlike the preschool boys who hid in tunnels and other enclosed structures. This sex difference was not evident after viewing a model deer (Coss \& Penkunas, 2016).

This background of nighttime antipredator behavior of nonhuman primates, coupled with the sexual-dinichism hypothesis, was used to test whether preschool boys and girls anticipated a similar pattern of spatial danger as a relict of arboreal nighttime antipredator behavior; thus, it seemed reasonable to test the hypothesis that preschool girls would remember being more fearful of a scary presence below the bed at night than would boys. Indeed, survey research on the nighttime fear of 3- to 4-year-old American boys and girls, comparing above, side, and below locations for a "scary thing" relative to their beds yielded a statistically significant interaction in which a larger frequency of girls reported the below location whereas a larger frequency of boys reported the side location. A statistically reliable interaction of sex and location was also obtained for the frequency distributions of adult remembrances of the location of the scary thing in their bedrooms as children. Moreover, and critically important for the current research, the preschool girls and women exhibited significantly similar frequency distributions for the above, side, and below locations for a scary thing (Coss, 2021).

A follow-up study by Hunt (1997) examined cross-national differences in adult remembrances of the locations of nighttime scary things relative to the bed by Americans, Batswana, Danes, Germans, Hondurans, and Zimbabweans. Hunt reported a significant main effect in which females remembered being more fearful than males of a scary presence under their beds as children. Cultural differences were also apparent in which American, Batswana, and Danish women were more fearful of something scary below their beds than were males whereas Honduran and Zimbabwean men and women were not appreciably different. Such cultural differences suggest that early social interactions, perhaps with parents and other relatives, might have influenced these remembrances of childhood nighttime fear, the primary topic of the current study. Together, these studies provide a compelling inductive argument that evolutionary processes contribute to sex differences in spatial fears at night in simulated antipredator behavior and in nonthreatening climbing behavior.

Whereas the research on sexual dinichism is an explicit test of an evolutionary hypothesis (see Coss \& Charles 2004), little research on the etiology of fear has focused on precise evolutionary explanations in the derivation of experimental questions. Previous research with an evolutionary flavor has examined the effects of shared environment by comparing the fearfulness of identical and fraternal twins and estimating the heritability of specific fears (e.g., Kendler et al., 1992; Skre et al., 2000; Torgersen, 1979). However, the experimental questions addressed by these twin studies were not based on a realistic appraisal of the historical circumstances in which certain fears might exhibit adaptive functions. For example, the correlations of twin fearfulness of small animals, such as rats, snakes, and spiders that afford distinct threats (Rose \& Ditto, 1983; Stevenson et al., 1992), reveal a common property of arousal, vigilance, and disgust (Davey et al., 1993) related to similarities of imagined situations rather than a cognitive assessment of the actual threats posed by these animals (Coss, 2003). And it must be noted that rats, snakes, and spiders typically represent a single dimension of fear that often include other animals (Scherer \& Nakamura, 1968; Ollendick et al., 1989; Fredrikson et al., 1996; Burnham \& Gullone 1997). Similarly, studies of visual scanning of dangerous and non-dangerous animals by children and adults show that dangerous animals capture attention more quickly (Penkunas \& Coss, 2013a, b; Yorzinski et al., 2014) 
and influence children's drawings (Lee \& Kang, 2012), but these perceptual studies shed little light on processes of fear acquisition (see Purkis \& Lipp, 2007).

\section{The Role of Experiences in the Development of Specific Fears}

Although twin studies typically examine the differential contributions of genetic and environmental effects in the manifestations of fearfulness, an examination of crosscultural differences might shed light on both evolved and culturally moderated fears. A number of studies have been conducted that investigate unique individual and cultural differences in patterns of fearfulness (e.g., Sidana, 1975; Farley et al., 1978; Klingman \& Wiesner, 1982, 1983; Field and Lawson 2003). For example, research by Ollendick and colleagues (1996), using the Fear Survey Schedule for Children-Revised, showed a significant main effect of country in which people from Nigeria, America, Australia, and China show different types of fears. Specifically, Ollendick and colleagues (1995) found that Nigerian children and adolescents reported a higher overall intensity of fears than did American, Australian, and Chinese children and adolescents. And other crosscultural differences have also been observed. For example, Hallowell (1938) asserted that the different beliefs of North American indigenous people and people in Western society moderated the ways threatening animals were perceived. Furthermore, not only might the unique and different experiences that individuals have as a result of different cultures moderate fear acquisition, the sociocultural context of these experiences might influence fear acquisition differently in females and males. Sex differences have emerged in previous studies including crosscultural comparisons in which females reported a higher level of fearfulness than did males (Lapouse \& Monk 1958; Bamber, 1974; Earls, 1980; Morris \& Kratochwill, 1983; Davidson et al., 1989; Dong et al., 1994; Tucker \& Bond, 1997; King et al., 1998).

With reference to sex difference in a single sociocultural context, sex difference in fear acquisition has also been found in cross-cultural studies (Fonseca et al., 1994). For example, Ollendick and colleagues (1996) found that American, Australian, and Chinese girls reported a higher overall intensity of fears than did boys (for imaginary fears, see Sayfan \& Lagattuta, 2009). In contrast, Nigerian girls and boys did not differ in their reported overall fearfulness.

In addition to cross-cultural comparisons of the social and environmental circumstances that precipitate behaviors, within-country ethnic group comparisons provide an excellent context for understanding the convergence of different ethnic experiences in the process of acculturation (e.g., BenetMartínez \& Karakitapoğlu-Aygün, 2003). As an example of this approach, comparing participants of different ethnicities drawn from within the USA, Myers and colleagues (1987) found that Chinese and Japanese participants with similar acculturation and socioeconomic backgrounds did not differ appreciably in their fears of a broad range of situations, including fear of animals and supernatural entities. However, Vietnamese participants, who differed markedly in their acculturation and socioeconomic level from the Chinese and Japanese, were much more fearful. While not exhaustive, these studies suggest that cultural factors can moderate patterns of fearfulness. On the whole, there is considerable controversy in the literature on the development of fear, and researchers should recognize the possible joint effects of evolution and culture in examining the development of fear (for discussions of the interplay of individual experiences and evolutionary processes in fear acquisition, see Marks, 2002; Poulton \& Menzies, 2002a, b; Rachman, 2002; for critiques of this viewpoint, see Kleinknecht, 2002; McNally, 2002; Mineka \& Öhman, 2002; Armfield, 2006; Öhman, 2009).

\section{Belief in Supernatural Entities and Fearfulness of Natural Hazards}

Individuals who immigrate to a different cultural setting often retain the cultural values and beliefs of their native countries, many of which include imagined or irrational organism-environment relationships. An important facet of these beliefs can include the reverence for supernatural essences or agencies that are believed to provide spiritual guidance, physical protection, or have malevolent intentions. With respect to the issue of malevolent intentions, Lemert (1997) and Atran (2002) argue that the concept of something evil might have an evolutionary origin, possibly the result of historical predatory attacks (reviewed by Russell, 1979; King et al., 1997; Treves \& Naughton-Treves, 1999; Coss \& Moore, 2002; Hart \& Sussman, 2008; Coss, 2021). For example, fear of the dark, which may arouse the sensations that something scary is lurking out there, is part of a broadly distributed fear that appears in many cultures. As discussed previously with respect to nighttime fear, many irrational fears originate in childhood, especially fear of the dark and dreams of being chased or attacked (Bauer, 1976; Beaudet, 1991; Hartmann, 1984). Therefore, it is conceivable that childhood nighttime fear might have a developmentally prolonged effect in shaping spiritual sensations of an undefined entity that is out there spatially. In relation to this idea, a positive correlation between level of fearfulness and religiosity (i.e., belief in supernatural entities) has been reported in previous studies (e.g., Klingman \& Wiesner, 1983; Wilson \& Miller, 1968). In addition, women reported that they believed in supernatural entities to a greater extent than did men (Blum, 1976; Haraldsson, 1985; Tobacyk \& Milford, 1983; Clarke, 1991). 


\section{Study Rationale}

Application of evolutionary hypotheses for empirical research in behavioral studies is typically applied to nonhuman species with well-studied phylogenies. The human lineage is the best studied in terms of the fossil record and historical habitat. Several distinct behavioral measures of humans and chimpanzees converge inductively in supporting the sexual-dinichism hypothesis (Doran, 1993; Coss \& Goldhthwaite, 1995; Coss \& Moore, 2002; Coss \& Charles, 2004; Coss, 2021). Natural selection on differential arboreal habitat use by each sex, constrained by sexual-size dimorphism, has been relaxed for at least 2.0 million years following the advent of East African Homo erectus with an intermediate level of sexual-size dimorphism inferred from later $H$. erectus footprints (Villmoare et al., 2019).

Cross-cultural research into this phenomenon might provide insight into the mutual relationships of sex differences reflecting evolutionary biases and differing cultural practices. Because previous research has shown cultural differences in levels of fearfulness among Southeast Asians (Myers et al., 1987), we selected for the current study Vietnamese and ethnic Chinese who immigrated to the USA after 4 years of age. Such an approach allowed comparisons of adults who, through the process of acculturation, have been experiencing similar cultural contexts afforded by advanced technologies (Herskovits, 1951). Due to our focus on the relationships of different types of fears and the logistical constraint of asking participants to complete long questionnaires in public settings, we did not investigate the roles of war-time experience or its aftermath that differed between these ethnic groups, religious affiliations, and current socioeconomic status on the development of fearfulness. The 1999-2001 World Values Surveys showed that among 68 countries sampled, the percentage of Chinese and Vietnamese men and women believing in an influential supernatural entity within an organized religion was below 13\% (Inglehart et al., 2004). Despite this low percentage for organized religions, both cultures consist of individuals who believe in evil spirits and report the appearances of ghost-like apparitions that emerge outside their proper places and must be chased away (cf. Bertrand, 1996; Mu-chou Poo, 2006). Complementary research on Americans showed that despite modern education and technology, younger individuals and women had a greater likelihood of ghost belief than older individuals. Moreover, the most and least religious individuals were less likely to believe in ghosts than those engaging in mid-level religious practices (Baker \& Bader, 2014, p. 573).

Again, the predominant theoretical interest of our research was examining the spatial effects of nighttime fear in childhood which are consistent with other evidences of historical natural selection associated with sexual dinichism since Pliocene times (reviewed by Coss 2021). We were particularly interested in exploring how children's nighttime fear, based on adult remembrances, would persist into adulthood and might influence other fears with spatial properties characterizing potentially dangerous situations. For example, a survey of German adults showed that they arranged their beds so they could view bedroom doors and windows from concealed vantage points (Spörrle \& Stich, 2010). Furthermore, since house architecture might play a role in promoting nighttime fear, we hypothesized that nighttime fear would be sensitive to spatial contexts, such as those produced by noises coming from below houses on elevated foundations over rivers or wet ground. We therefore predicted that fear of something scary below the bed would be augmented greatly for young children who had lived in houses on raised foundations compared with those who had lived in houses on dry ground.

Other attributes of interest were familial influences on fearfulness. In previous research, family context, such as marital conflict, has been shown to elevate children's nighttime fear (Gordon \& King, 2002). With reference to the familial context in conjunction with the findings that children's common fears are attributed to negative information regarding the fearful circumstances (e.g., Gerull \& Rapee, 2002; Muris et al., 2003; Ollendick \& King, 1991), we were interested in uniquely determining whether parents or family members used negative information about ghosts or monsters to discipline children (see Rachman, 1977 for theoretical discussion of the effect of negative information and the review by King et al., 1998). More specifically, comparative study of Vietnamese and ethnic Chinese would allow an examination of the effects of specific provocative situations in which children's fears were capitalized upon by parents or older relatives to discipline children, and whether such discipline had affected the manifestation of adult nighttime and daytime fears with spatial properties.

One source of natural selection on hominins foraging or moving about would have been the encounters with venomous spiders and the failure to avoid envenomation. Generally, the web-dwelling spiders have neurotoxic venom, and the non-web dwellers have cytotoxic venom causing serious tissue necrosis. African recluse spiders of the genus Sicarius and the neurotoxic Latrodectus, the button or widow spiders, would have constituted serious historical threats to hominins. Recluse spiders superficially resemble harmless web-dwelling spiders Cheiracanthium and the harmless lycosids, the family of wolf spiders that includes large tarantulas exhibited in zoological parks. Although bites from highly venomous spiders might not have been lethal to our smaller-bodied ancestors, incapacitation resulting from spider bites can affect fitness by increasing vulnerability to predators and death from dehydration and serious infection. Thus, natural selection would have operated on effective spider 
recognition and avoidance (see McNally, 2002, p. 170 for a critique). It is therefore not surprising that fear of spiders is one of the most pronounced fears in childhood (e.g., Lane \& Gullone, 1999; LoBue \& DeLoache, 2010; Merckelbach et al., 1996; Muris et al., 1997a, b, 2002a, b), and it is often perceived to engender the same negative affect as do other circumstances that characterize uncertain threats, including ghosts (Scherer \& Nakamura, 1968). We thus hypothesized that childhood fear of spiders might exhibit developmental stability and thus contribute to adult fears that also reflect uncertain threats (Ferrari, 1986). Also, the aforementioned assertions of evolutionary influences on perceptual phenomena, such as apparitions and persistent beliefs in spiritual entities (Atran, 2002; Lemert, 1997), might be supported by their association with childhood nighttime fear of scary things. Finally, to counter any assertion that adult remembrances of the nighttime locations of something scary relative to their beds as children examined herein might not characterize childhood fear accurately, it must be emphasized again that previous research showed that preschool boys and men exhibited very similar recollections and preschool girls and women exhibited significantly similar recollections (Coss, 2021).

\section{Method}

\section{Participants}

The Vietnamese who completed the questionnaire consisted of 211 individuals (96 males and 115 females) who were born in Vietnam; they had an average age of 33.7 years (range: 18 to 81 years). These Vietnamese had spent an average of 14.5 years in the USA. The ethnic Chinese who completed the questionnaire consisted of 263 individuals (89 males and 174 females) who were born in China, Hong Kong, or Taiwan; their average age was 34.8 years (range: 15 to 82 years). These ethnic Chinese had lived in the USA for an average of 8.2 years. With respect to house architecture, $21.0 \%$ of Vietnamese males reported that they slept as children in houses with raised foundations whereas only $4.0 \%$ of Chinese males reported having done so. Similarly, $16.5 \%$ of Vietnamese females reported living as children in houses with raised foundations compared with $3.7 \%$ of Chinese females.

\section{Instrument}

A 25-item questionnaire employing four 5-point ordinal scales was developed that examined a wide range of spatial and non-spatial fears characterizing both biotic and abiotic circumstances. Six of these questions were fillers, designed to mask any perceived coherence of the spatial questions of experimental interest. The first scale asked participants to estimate the occurrence of fearful events using the following terms: $1=$ never, $2=$ rarely, $3=$ some times, $4=$ often, $5=$ very often. Questions that centered on remembered childhood experiences emphasized level of nighttime spatial fear, parental discipline capitalizing on the child's fearfulness, and spider fear. There were four questions on childhood occurrences of nighttime fears: (1) "When you were little, did you ever think there were scary things in your room at night?" (2) "Was the scary thing located above you, such as near or above ceiling, as on the 2nd floor?" (3) "Was the scary thing located to your side, such as behind closet doors/s, cabinets, or outside windows?" (4) "Was the scary thing located below you, such as underneath the bed, on floor (or 1st floor)?" The parental discipline question was designed to reveal whether there were cultural and sex-specific effects: (5) "Do you ever remember your parents or older relatives telling you that if you did not behave as a good boy or girl that a monster or ghost would get you?" The question on spider fear was (6) "When you were little, how comfortable were you after you suddenly encountered a spider on a web?".

Adult situations in the USA reexamined nighttime fear and concern about an uncertain sensed presence out there in relation to specific vantage points. Several questions dealt with situations in which such sensed presences had malevolent or protective intentions and others that posed potential threats without intentions. These questions were (7) "Some adults in bed occasionally feel the nearby presence of something scary at night. Are there ever times at night when you feel the presence of something scary lurking below the bed?" (8) "When you feel that something dreadful is suddenly going to happen to you, is the threat unspecific and difficult to identify and locate?" (9) "Do you find yourself uncomfortable walking by a large dense bush during the night?" (10) "When crossing a field with knee-high grass, do you ever think about encountering a snake?" (11) "When walking into a cobweb, do you worry about a spider biting you?" (12) "While outside during a thunderstorm, do you ever feel that you could be a target of a strike?" (13) "Have there ever been times at night when you thought that you saw something large appear briefly near you or move near you but later confirmed that nothing was really there?" (14) "Are there ever moments when you feel a Greater Being influencing your life?".

The second scale examined the degree of comfort that participants experienced during specific situations, as denoted by the following terms: $1=$ very comfortable, $2=$ somewhat comfortable, $3=$ indifferent, $4=$ somewhat uncomfortable, $5=$ very uncomfortable. (15) "How comfortable do you feel standing close to small rodents in waist-high 
zoo exhibits?" (16) "How comfortable do you feel standing close to large hairy spiders in waist-high zoo exhibits?" (17) "How comfortable do you feel standing close to snakes in waist-high zoo exhibits?".

A motivational scale examined the participant's willingness to explore an unfamiliar setting using the following terms: $1=$ eagerly, $2=$ agreeably, $3=$ with coaxing, $4=$ only if pressured, $5=$ never. (18) "How willing are you to explore an unfamiliar outdoor setting (e.g., park, hiking trail, new part of town)?" The level of annoyance to a specific provocative sound (e.g., Halpern et al., 1986) was examined using the following terms: $1=$ not at all, $2=$ slightly, $3=$ moder ately, $4=$ very, $5=$ exceedingly. (19) "How annoying is the rasping sound of fingernails scraping a chalkboard?".

The following filler questions were not analyzed statistically: (20) "How willing are you to taste new foods?" (21) "When using an electric shaver or hair dryer over a sink filled with water, do you ever worry about accidentally dropping it into the water?" (22) "How comfortable do you feel sleeping next to someone with a bad cold?" (23) "How comfortable do you feel climbing a sturdy 6-foot step ladder to the top rung?" (24) "How comfortable do you feel sitting on an unfamiliar toilet?" (25) "When driving down the highway at $60 \mathrm{mph}$, how many car lengths do you typically leave between you and the car in front of you?" This questionnaire was originally approved under Human Subjects Review Committee Protocol 96-482R and extended under IRB exemption 200,311,298-1.

\section{Procedure}

Both the Vietnamese and ethnic Chinese were surveyed in similarly diverse settings in California, with the majority drawn from students at the University of California, Davis campus. Other public settings for questionnaire distribution and recovery were Vietnamese and Chinese supermarkets. All Chinese participants were fluent in English. For older Vietnamese individuals who were somewhat deficient in English, several questions were clarified in Vietnamese. Participants agreed to participate after reading the permission form or oral description.

\section{Statistical Analyses}

Multinomial log-linear analyses with maximum likelihood estimations that included data partitioning (Agresti, 2002) were used to analyze the rating frequencies for questions on remembrances of childhood nighttime fears (questions $1-4)$, parental threats that a monster or ghost would get them if they did not behave as children (question 5), and adults fears of something scary below the bed (question 7). For these analyses, ethnic group and sex were predictor variables, and the five ratings of remembered occurrences were the response variables. In addition, multivariate analyses examined relationships among the variables using exploratory factor analyses (EFAs) applied to each ethnic group. The latent variables from the EFAs were incorporated into four structural equation models that examined for each ethnic group the predictive properties of sex and remembrances of childhood nighttime fear, parental threats, and childhood encounters with spiders.

\section{Results}

\section{Childhood Nighttime Fear}

Examination of the frequencies of nighttime fears remembered from childhood indicated that $9.95 \%$ of Vietnamese and $21.62 \%$ of ethnic Chinese reported that they never thought that something scary was in their room at night (question 1). In combination with ratings of remembered fearfulness, log-linear analysis did not show any statistically significant interactions of ethnic group or sex and ratings of childhood thoughts of scary things. Analyses of the above, side, and below locations of the scary thing relative to the beds (questions 2-4) were restricted to only individuals who reported fearfulness in a spatial context. The interaction of ethnic group and fearfulness was statistically significant for only the below the bed location, Likelihood ratio $x_{4}{ }_{4}(N=393)=25.24$, $p<0.001, d=0.52$, a comparison showing that a larger proportion of Vietnamese reported higher fear ratings than did ethnic Chinese. A statistically significant interaction of sex and fearfulness of a scary thing below the bed indicated that women reported that they were more fearful as children than were men, Likelihood ratio $x_{4}^{2}(N=393)=10.45, p<0.001$, $d=0.33$, a finding consistent with the hypothesized sex difference for fear of something scary in this spatial location (Fig. 1).

Because so few ethnic Chinese as children slept in houses with raised foundations, we examined only the nighttime remembrances of something scary below the bed in Vietnamese as a function of houses with ground level and raised foundations. To adjust for small sample sizes in the raised foundation group, the 5-point scale of fearfulness was condensed into two categories: low fear $=$ never, rarely, and sometimes, and high fear $=$ often and very often. With this revised scale, the interaction of house foundation and fearfulness was statistically significant, with the largest proportion of individuals sleeping in houses with ground-level foundations reporting low fear of something scary below the bed, Likelihood ratio $x^{2}{ }_{1}(n=172)=4.14$, $p<0.05, d=0.35$. Among these latter individuals, the interaction of sex and the original 5-point scale of fearfulness were also statistically significant, with a larger proportion of women reporting greater fear than did men, Likelihood ratio $x_{4}^{2}(n=140)=11.11, p<0.025, d=0.59$. 


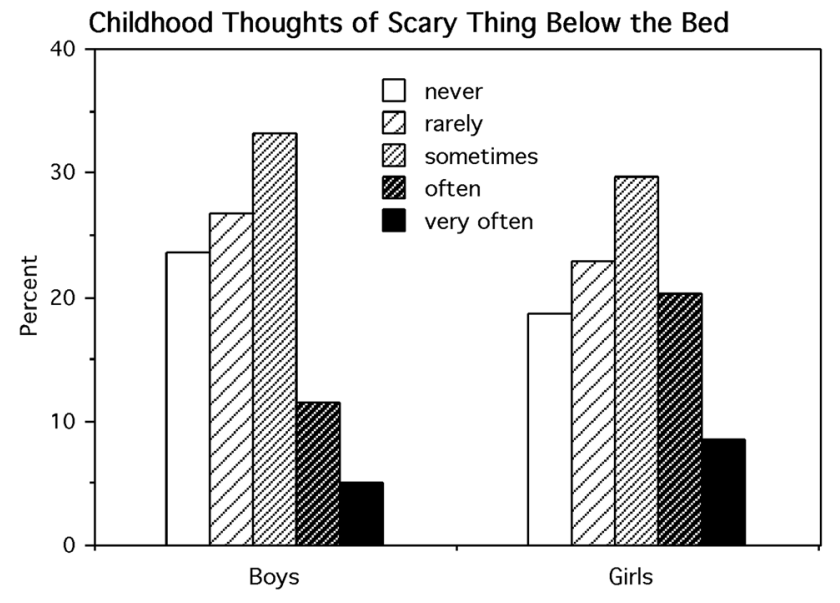

Fig. 1 Comparison of sex differences in the combined percentages of childhood thoughts of a scary thing below the bed by Vietnamese and ethnic Chinese $(N=393)$. The interaction of sex and scale of fearfulness was statistically significant $(p<0.001)$

\section{Adult Nighttime Fear}

Some adults still feel the nighttime presence of something scary lurking below the bed, a property that might reflect the continuity of childhood nighttime fears coupled with fearful lifetime experiences (e.g., Hunt, 1997). The analysis used to test question 7 resulted in a statistically significant interaction of ethnic group and the 5-point scale of fearfulness, Likelihood ratio $x^{2}{ }_{4}(N=470)=35.37$, $p<0.001, d=0.57$. Ethnic Chinese constituted the largest proportion of individuals reporting that they never felt the presence of something scary lurking below their beds (Fig. 2). The interaction of sex and fearfulness was also statistically significant, Likelihood ratio $x^{2}{ }_{4}(N=470)=15.59, p<0.001, d=0.37$, with women reporting that they felt a more frequent occurrence of a scary presence below them than did men. Furthermore, the three-way interaction of ethnic group, sex, and fearfulness was statistically significant, Likelihood ratio $x^{2}{ }_{4}$ $(N=470)=12.60, p<0.025, d=0.33$. The source of this interaction is apparent in Fig. 2, which shows that ethnic Chinese males were not as fearful as their female counterparts, Likelihood ratio $x_{4}^{2}(n=260)=12.63, p<0.025$, $d=0.45$.

\section{Threatening Children to Behave}

Question 5 investigated the issue of ethnic differences in parents or older relatives threatening children that a monster or ghost would get them if they did not behave. We were particularly interested in whether these ethnic groups differed in the degree that boys or girls were threatened by older family members. The interaction of ethnic group and

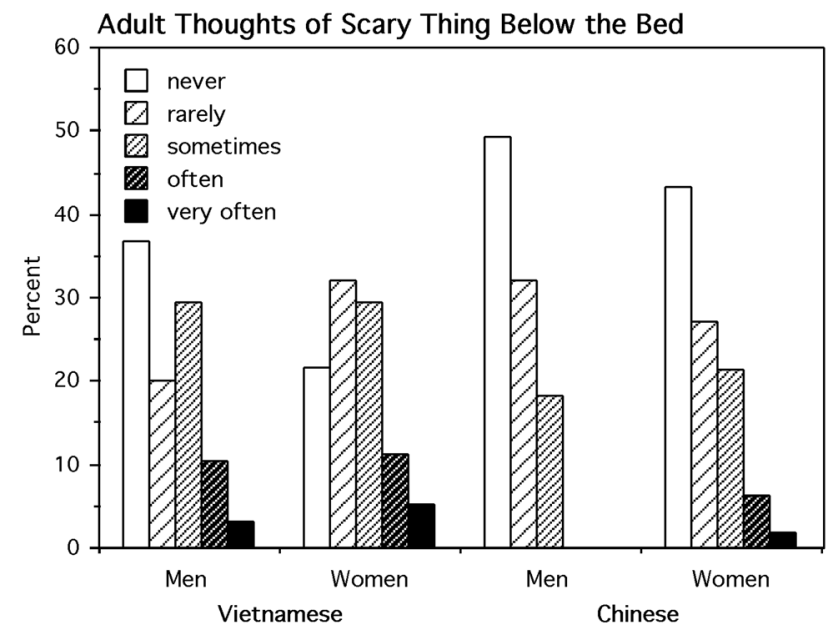

Fig. 2 Comparison of the percentages of adult thoughts of a scary thing below the bed $(N=470)$. Data partitioning revealed that ethnic Chinese males were not as fearful as Chinese females $(p<0.025)$

remembered occurrences of parental threats was statistically significant, Likelihood ratio $x_{4}^{2}(N=470)=18.38, p<0.001$, $d=0.40$. Vietnamese reported that their relatives threatened them more frequently than the threats reported by ethnic Chinese (Fig. 3). In both ethnic groups, males and females remembered being threatened at similar frequencies.

\section{Fear of Spiders During Childhood}

Because the Vietnamese and ethnic Chinese experienced somewhat different environmental settings, notably a greater variety of house architecture in rural settings, it was of interest to determine if they differed in their remembered level of comfort in the common occurrence of suddenly encountering a spider on a web in childhood (question 6). In this analysis, there were no statistically significant interactions of ethnic group or sex and levels of discomfort, which were among highest (range $=11.9$ to $23.6 \%$ for very uncomfortable) reported by the participants.

\section{Exploratory Factor Analyses}

Our questionnaire was designed to explore ethnic and sex differences in several facets of childhood fears in spatially defined settings. Several questions addressed easily perceived adult risks, such as observing animals in zoos, whereas others described adult situations with much greater uncertainty. This latter aspect was especially evident for questions describing potentially threatening outdoor situations. Theoretical considerations generated a model of hypothesized relationships among constructs relating to childhood and adult experiences. Four items were used as single-indicator measures. These were Childhood fears 


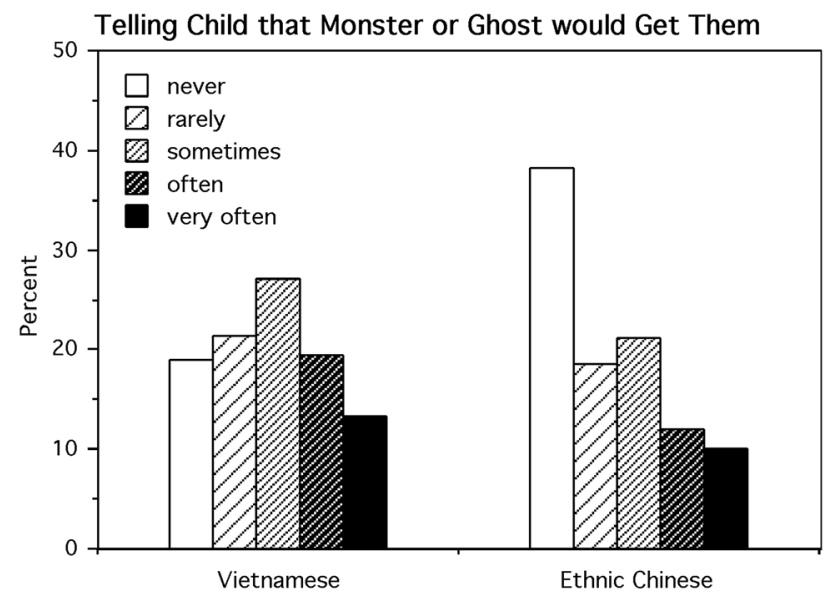

Fig. 3 Comparison of the percentages of the remembered situation in which parents or older relatives told the children that a ghost or monster would get them if they did not behave $(N=470)$. The interaction of ethnic group and remembered occurrences of parental threats was statistically significant $(p<0.001)$

(question 1), Parental Threats (question 5), Childhood Fear of Spiders (question 6), and Influence of a Greater Being (question 14). For the remaining constructs, Indeterminate Agents, Environmental Uncertainty, and Predictable Animals, several items (questions 7-13 and 15-19) were considered potential indicators of these underlying constructs. For these 12 items, exploratory factor analyses were conducted, treating each ethnic group separately. Theory, in conjunction with indices of model fit, was used to determine the number of factors to retain. Two common indices of model fit are reported: $\chi^{2}$ and the root mean squared error of approximation (RMSEA). $\chi^{2}$ is an index of perfect fit, such that a model that fits the data perfectly results in no correlations among the observed items after the factors are taken into account. In practice, this is an unreasonable expectation of a model because even in the population, it is often unreasonable to assume that a small number of factors could perfectly account for the correlations among scale items. An alternative measure of fit, the RMSEA, was developed based on the idea that a good fitting model does not provide a perfect fit but rather provides a close fit (Steiger \& Lind, 1980; Browne \& Cudeck, 1992). In a factor-analysis model, this would suggest that once the appropriate number of factors is taken into account, the items would have negligible correlations among them, even in the population. In interpreting the solutions here, factor loadings $\geq 0.4$ were considered large. An oblique rotation, Promax, was used because it was not assumed a priori that the resulting factors were uncorrelated. Data were analyzed using Mplus version 2.01 (Muthén \& Muthén, 1998). Given that items were measured on ordinal scales, the factor analysis was based on the assumption that scale points were not necessarily equally spaced, as they would be for interval-level data. Therefore, an estimation procedure designed for analysis of ordinal level variables was used (Muthén \& Muthén, 1998).

For Vietnamese, the best fitting and most theoretically interpretable solution was a 4-factor model $\left[x^{2}(18\right.$ $d f)=26.1, p=0.10$, RMSEA $=0.047]$. For ethnic Chinese, a 3 -factor solution was $\left[x^{2}(22 d f)=27.9, p=0.10\right.$, RMSEA $=0.033]$. The results for both groups, summarized by factor loadings and factor correlations, are given in Table 1. As shown in Table 1, solutions were comparable for the two ethnic groups: Indeterminate agents was indicated by items 7, 8, and 13. Environmental uncertainty was indicated by items 9 and 10, and predictable animals was indicated by items 15,16 , and 17 . For Vietnamese, a fourth factor, indicated by questions 11 and 12, also reflected environmental uncertainty but was weakly correlated with the first factor relating to the environment. With regard to the constructs of interest, we chose to retain the three subsets of items common to both groups. The results from the exploratory analyses were then used to test hypotheses about relationships among factors relating to childhood and adult experiences. Given that some constructs were represented by single items and others represented by multiple items, it was possible to take into account measurement error for some of the constructs (i.e., those for which multiple items were available). Analyses based on structural equation modeling, in which some variables were considered observed and others latent, are described below.

\section{Structural Equation Modeling}

One variable, the evolutionary relict of adult expectancies of predatory attacks manifested as children's nighttime fear, was hypothesized as a predictor variable of current adult fears and the influence of a greater being. We hypothesized that parental threats, in which family members threatened children that a monster or ghost would get them if they did not behave, would mediate the relationship between childhood nighttime fear and the latent variable, indeterminate agents, indicated by something scary lurking under the bed; the difficulty of locating a dreadful, unspecific threat; and the brief appearances of large apparitions. The measure of childhood nighttime fear was predicted to influence two additional latent variables: environmental uncertainty of potential encounters with animate threats lurking behind a bush or in grass (environmental uncertainty) and comfort while viewing animals in zoo exhibits (predictable animals). Additionally, the measure of childhood nighttime fear was predicted to affect the influence of a greater being. Because of the indeterminate properties of sudden spider movement on a web, the second childhood variable, the comfort of encountering a spider on a web, was predicted to influence the latent variable, indeterminate agents. 
Table 1 Rotated factor structures for adult Vietnamese and ethnic Chinese fears

\begin{tabular}{|c|c|c|c|c|c|c|c|}
\hline \multirow[b]{3}{*}{ Item } & \multicolumn{7}{|c|}{ Factor loadings: Promax rotation } \\
\hline & \multicolumn{4}{|c|}{ Vietnamese } & \multicolumn{3}{|c|}{ Ethnic Chinese } \\
\hline & Factor 1 & Factor 2 & Factor 3 & Factor 4 & Factor 1 & Factor 2 & Factor 3 \\
\hline 7. Fear of something scary below bed & 0.726 & -0.059 & 0.074 & 0.156 & 0.796 & -0.124 & -0.065 \\
\hline 8. Something dreadful is going to happen & 0.529 & 0.179 & 0.020 & 0.099 & 0.504 & 0.229 & 0.000 \\
\hline 9. Walking by a dense bush at night & 0.178 & 0.743 & 0.039 & -0.035 & 0.091 & 0.649 & -0.026 \\
\hline 10. Encountering a snake in knee-high grass & -0.034 & 0.710 & -0.033 & 0.182 & -0.075 & 0.760 & 0.008 \\
\hline 11. Walking into cobweb and spider biting & 0.130 & -0037 & 0.184 & 0.641 & 0.310 & 0.150 & 0.373 \\
\hline 12. Target of a lightning strike & -0.042 & 0.227 & -0.186 & 0.757 & 0.292 & 0.185 & 0.054 \\
\hline 13. Saw something briefly near you & 0.656 & 0.125 & -0.046 & -0.174 & 0.569 & 0.113 & -0.037 \\
\hline 15. Comfort standing close to rodents in zoo & 0.077 & -0.070 & 0.499 & 0.197 & 0.101 & -0.168 & 0.619 \\
\hline 16. Comfort standing close to spiders in zoo & 0.089 & -0.045 & 0.926 & -0.113 & -0.088 & 0.046 & 0.848 \\
\hline 17. Comfort standing close to snakes in zoo & -0.287 & 0.234 & 0.527 & 0.017 & -0.038 & 0.049 & 0.625 \\
\hline 18. Explore unfamiliar outdoor setting & 0.012 & 0.240 & -0.043 & 0.041 & 0.268 & -0.168 & 0.246 \\
\hline \multirow[t]{5}{*}{ 19. Fingernails scraping a chalkboard } & -0.024 & 0.222 & 0.122 & -0.232 & -0.350 & 0.187 & 0.315 \\
\hline & \multicolumn{7}{|c|}{ Promax factor correlations } \\
\hline & \multicolumn{4}{|c|}{ Vietnamese } & \multicolumn{3}{|c|}{ Ethnic Chinese } \\
\hline & Factor 1 & Factor 2 & Factor 3 & Factor 4 & Factor 1 & Factor 2 & Factor 3 \\
\hline & $\begin{array}{c}1.000 \\
0.2777 \\
-0.017 \\
0.304\end{array}$ & $\begin{array}{l}1.000 \\
0.279 \\
0.260\end{array}$ & $\begin{array}{l}1.000 \\
0.307\end{array}$ & 1.000 & $\begin{array}{l}1.000 \\
0.351 \\
0.343\end{array}$ & $\begin{array}{l}1.000 \\
0.382\end{array}$ & 1.000 \\
\hline
\end{tabular}

Structural equation modeling was used to test specific relationships among constructs. Effects of sex on outcome measures and sex differences in the hypothesized relationships were also tested. For the first set of models tested for both Vietnamese and ethnic Chinese, no differences between males and females in any of the hypothesized paths from childhood to adult experiences were detected. These absences of sex differences in the estimated paths concerning childhood and adult experiences were tested by performing a multiple-group analysis to allow paths to vary between males and females. Because no differences were detected, the results given are based on a single-group analysis.

For Vietnamese $(N=205$ : Fig. 4$)$, childhood nighttime fear reliably influenced indeterminate agents and environmental uncertainty. Childhood nighttime fear also reliably influenced the latent measure indeterminate agents via the mediating variable, parental threats, but not the influence of a greater being. Sex differences in the mean levels of indeterminate agents, environmental uncertainty, and the influence of a greater being were detected, suggesting that Vietnamese females had elevated levels of these types of adult experiences. Counter to the hypotheses, the measure of childhood fear of spiders was not a reliable predictor of indeterminate agents, and the measure of childhood nighttime fear was not a reliable predictor of predictable animals.

Ethnic Chinese ( $N=250$ : Fig. 5) exhibited a reliable pathway in which childhood nighttime fear influenced the latent measure of indeterminate agents, where childhood nighttime fear had both a direct effect on indeterminate agents and an indirect effect as mediated by parental threats. Environmental uncertainty and influence of a greater being were both reliably predicted by childhood nighttime fear, such that greater levels of childhood nighttime fear tended to be related to both elevated adult reports of fears of environmental uncertainty and the influence of a greater being. Sex differences in the mean levels of environmental uncertainty and predictable animals were detected, suggesting that ethnic Chinese females have elevated levels of these types of adult fears. Contrary to our hypotheses, the predictor variable of childhood comfort when suddenly encountering a spider on a web was not reliably associated with the latent measure indeterminate agents as was found for Vietnamese. Further, the measure of childhood nighttime fear was not a reliable predictor of predictable animals. Between ethnic-group comparisons were done by computing $95 \%$ confidence intervals for the effects tested by the model. All estimated intervals between groups overlapped, suggesting that the hypothesized effects did not differ between the two ethnic groups.

Structural equation modeling was then used to test similar relationships specified in the previous models, but in these cases, we were interested in examining the effects of childhood nighttime fear as they related to specific locations relative to the bed. For these analyses, we considered only those individuals acknowledging childhood fears of something 


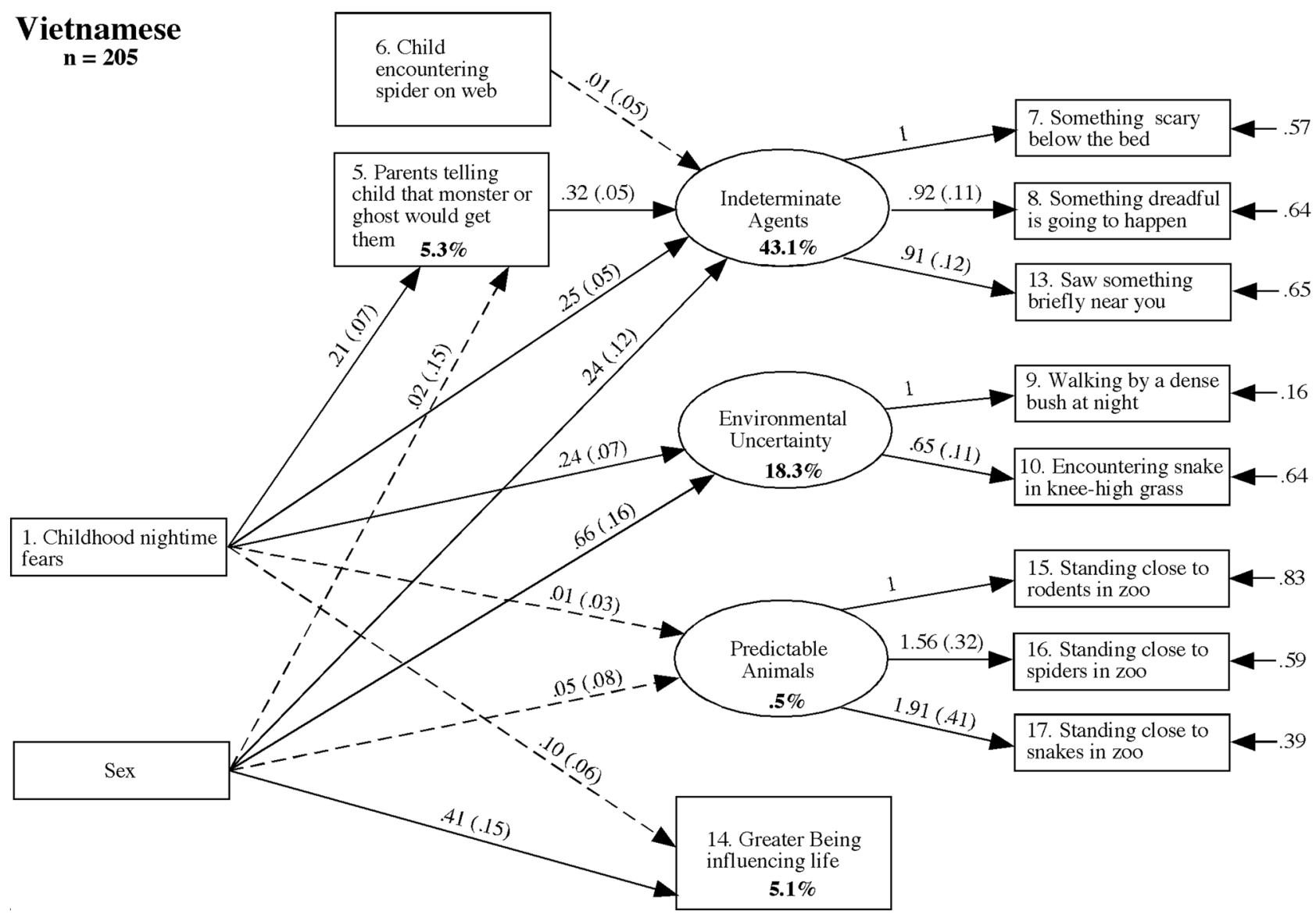

Fig. 4 Structural equation model of Vietnamese illustrating the pathways of influence of predictor variables (childhood fear of spiders and childhood nighttime fears of scary things) and the mediating variable of familial threats on adult fears. Solid paths depict statistically

scary (question $1 \geq 2$ "rarely"). In place of the single measure of childhood nighttime fear, we included each of the three location variables relating to this variable and studied their effects on the outcomes as specified previously. Unlike the previous set of analyses, some sex differences in the hypothesized associates were detected. These findings are discussed below.

For Vietnamese ( $N=189$ : Fig. 6$)$, the above and below locations (questions 2 and 4), reliably influenced indeterminate agents, such that higher levels of current fears of indeterminate agents were related to childhood fear of something scary tending to come often from these two locations. However, the effect of the below location was statistically significant for females only. Both the above and below locations also reliably influenced the latent measure indeterminate agents via the mediating variable, parental threats. The side location (question 3 ) reliably influenced environmental uncertainty, with higher levels of environmental fears in adulthood related to childhood fear of something scary tending to come often from this location. No sex differences significant influences, with $p<0.05$, two-tailed. Standardized path coefficients with standard errors in parentheses are shown next to the pathways

in the mean levels of any of the outcome variables were detected. The measure of childhood fear of spiders did not reliably predict indeterminate agents, and none of the above, side, and below location measures reliably predicted predictable animals or influence of a greater being.

For ethnic Chinese $(N=203$ : Fig. 7$)$, the above location reliably influenced indeterminate agents, such that higher levels of current fears of indeterminate agents were related to childhood fear of something scary tending to come often from above. However, parental threats did not mediate this relationship. Similar to the Vietnamese, the side location (question 3) reliably influenced environmental uncertainty, with higher levels of environmental fears in adulthood related to childhood fear of something scary tending to come often from this location. Environmental uncertainty was higher, on average, for females. Parental threats was reliably predicted by the side location. The measure of childhood fear of spiders was not a reliable predictor of indeterminate agents, and none of the location measures reliably predicted influence of a greater being. 


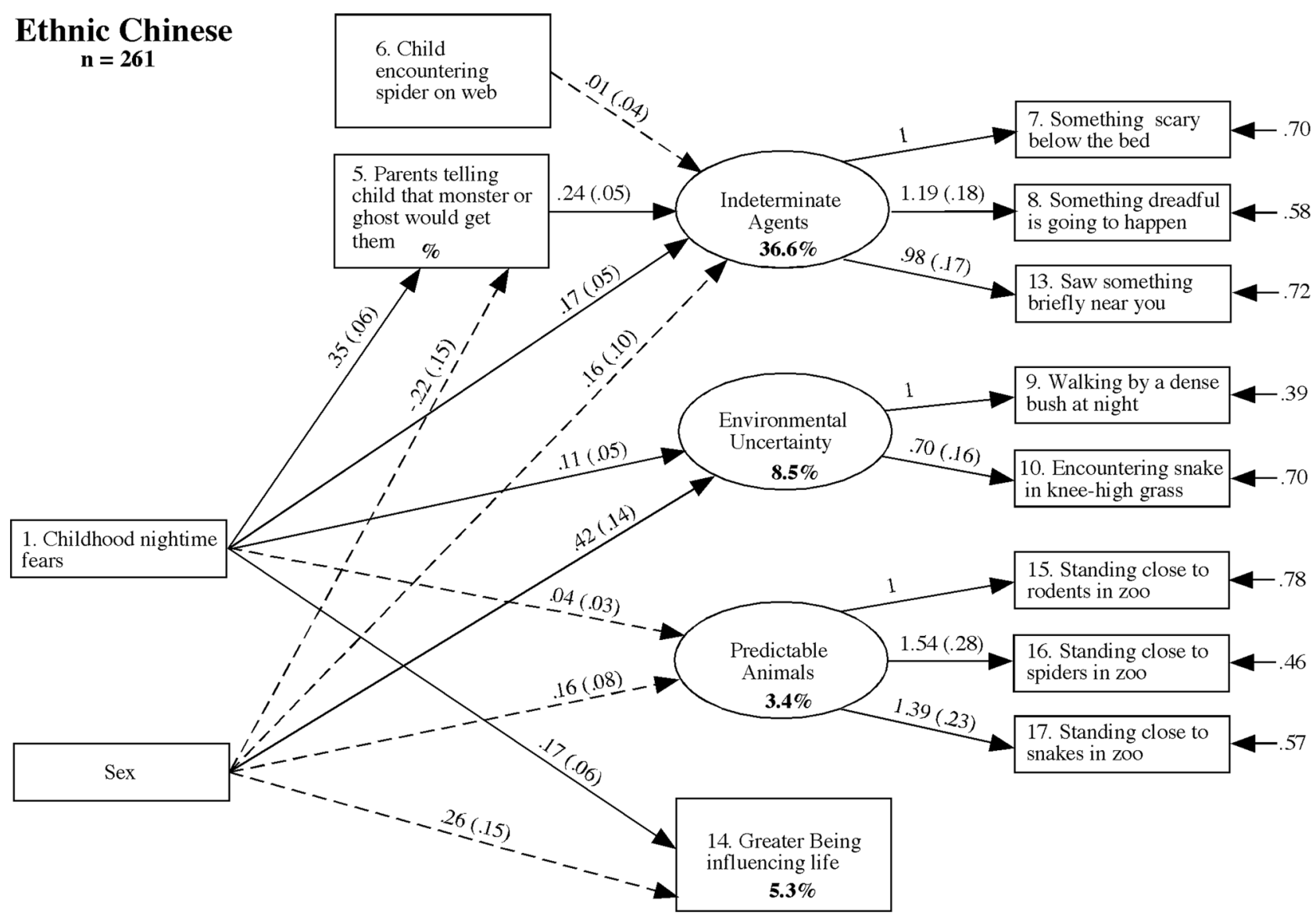

Fig. 5 Structural equation model of ethnic Chinese illustrating the pathways of influence of predictor variables (childhood fear of spiders and childhood nighttime fears of scary things) and the mediating variable of familial threats on adult fears. Solid paths depict statis-

\section{Discussion}

The aim of the current study was to examine the relationship of children's nighttime fear, which has spatial attributes, and adult spatial fears. From the cross-cultural perspective, we were especially interested in determining whether parental discipline, which capitalized on children's nighttime fear, enhanced adult spatial fears. Examination of this type of parental discipline was inspired in part by the theoretical view of Rachman (1977 p. 384) who proffered the notion that information and instructional processes in the child's earliest years might influence the etiology of commonly expressed fears that emerge later in development. The choice of studying the spatial aspects of nighttime fear was due, in part, to empirical evidence suggesting that modern humans retain sex differences in behavioral propensities that arguably characterize historical sexual dinichism (Coss \& Goldthwaite, 1995; Coss \& Moore, 2002; Coss \& Charles, 2004; Coss, 2021).

Recall that the sexual-dinichism hypothesis asserts that smaller-bodied females would have used trees more tically significant influences, with $p<0.05$, two-tailed. Standardized path coefficients with standard errors in parentheses are shown next to the pathways

effectively for foraging and nighttime refuge from predators than would their male counterparts (e.g., Susman et al., 1984). Nighttime refuge in trees would have likely engendered a consistent nightly concern that something dangerous could attack from below as it currently does in most nonhuman primates (Anderson, 1984; Reichard, 1998; Ramakrishnan \& Coss, 2000, 2001). We found support for this hypothesis, in that remembrances of women as children and adults in both ethnic groups showed a greater fearfulness of something scary below their bed than did men, as is apparent in the univariate analyses of childhood and adulthood fears of something scary below the bed at night (Figs. 1 and 2). Also, with reference to the development of these fears, it must be noted that the much lower frequencies of high-level fear in participants as adults may reflect their greater rationality and life experience.

Consistent with our hypothesis that house elevation might influence childhood nighttime fear, the Vietnamese who slept in houses with raised foundations exhibited the greatest fearfulness of something scary lurking below, a property 


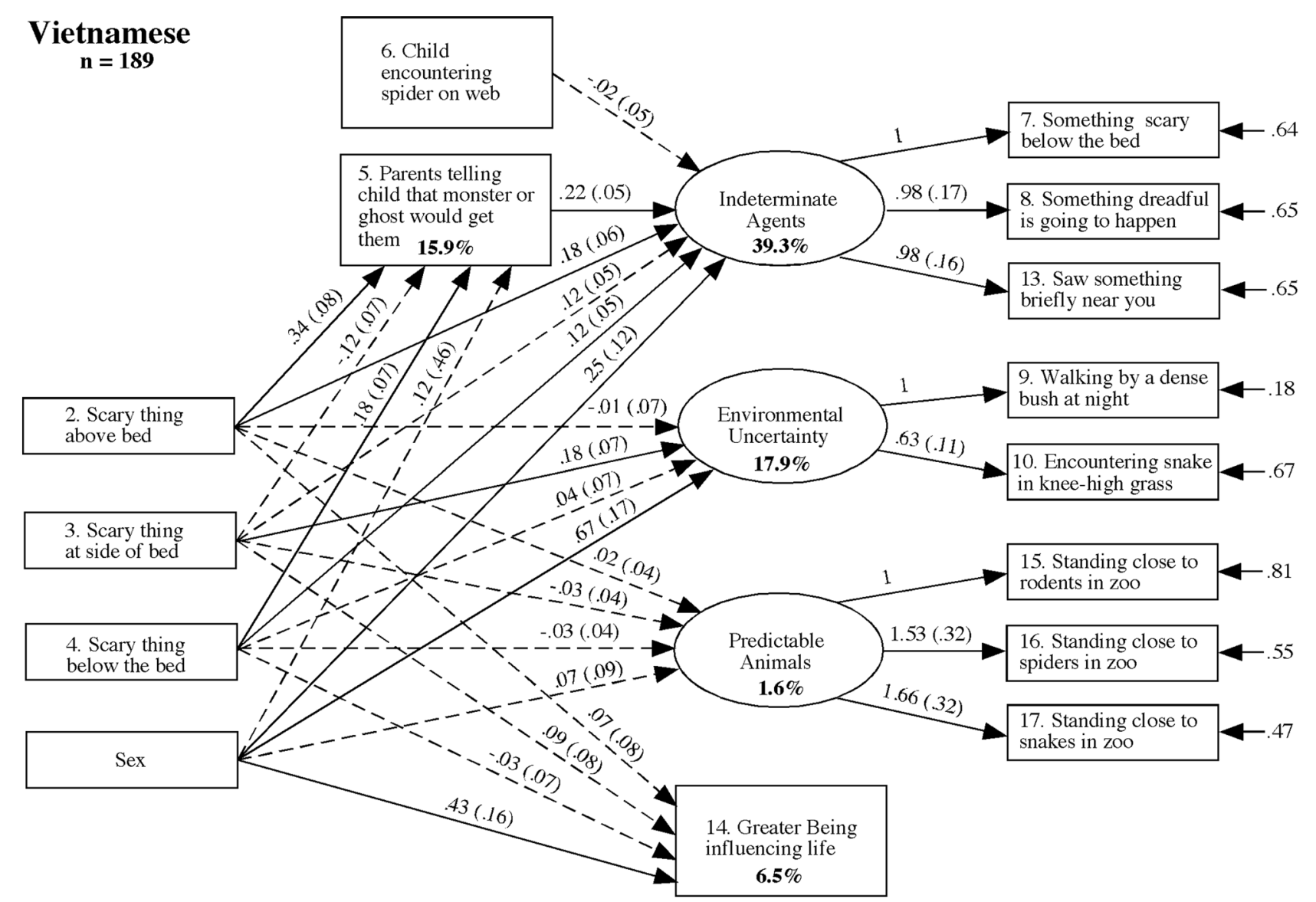

Fig. 6 Structural equation model of Vietnamese illustrating the pathways of influence of predictor variables (childhood fear of spiders and the spatial aspects of childhood nighttime fears of a scary thing relative to the bed) and the mediating variable of familial threats on adult fears. Solid paths depict statistically significant influences, with $p<0.05$, two-tailed. Standardized path coefficients with standard errors in parentheses are shown next to the pathways

latent variable that includes the adult fear of something scary below the bed. It is important to note that the Vietnamese also reported that they were disciplined as children more frequently in this manner than the ethnic Chinese, a finding that supports Rachman's (1977) theoretical view of the effects of negative information.

In conjunction with the association of childhood nighttime fear and adult fears of indeterminate agents, characterized by apparitions, unspecific threats, and fear of something scary below the bed in both ethnic groups, the association of childhood nighttime fear and adult spiritual sensations in ethnic Chinese (cf. Figs. 4 and 5) suggests a common framework for appraising the potential uncertainty afforded by the sense of ethereal presences out there. Childhood fear of the dark, which is replete in the phobia literature (e.g., Muris et al., 1997a, b; Coss, 2021), appears to reflect historical continuity of the anticipation that nighttime is dangerous. Thus, nighttime fear results from both the inability to detect something considered dangerous that is suspected of being present and assumptions that whatever is lurking out there has much 


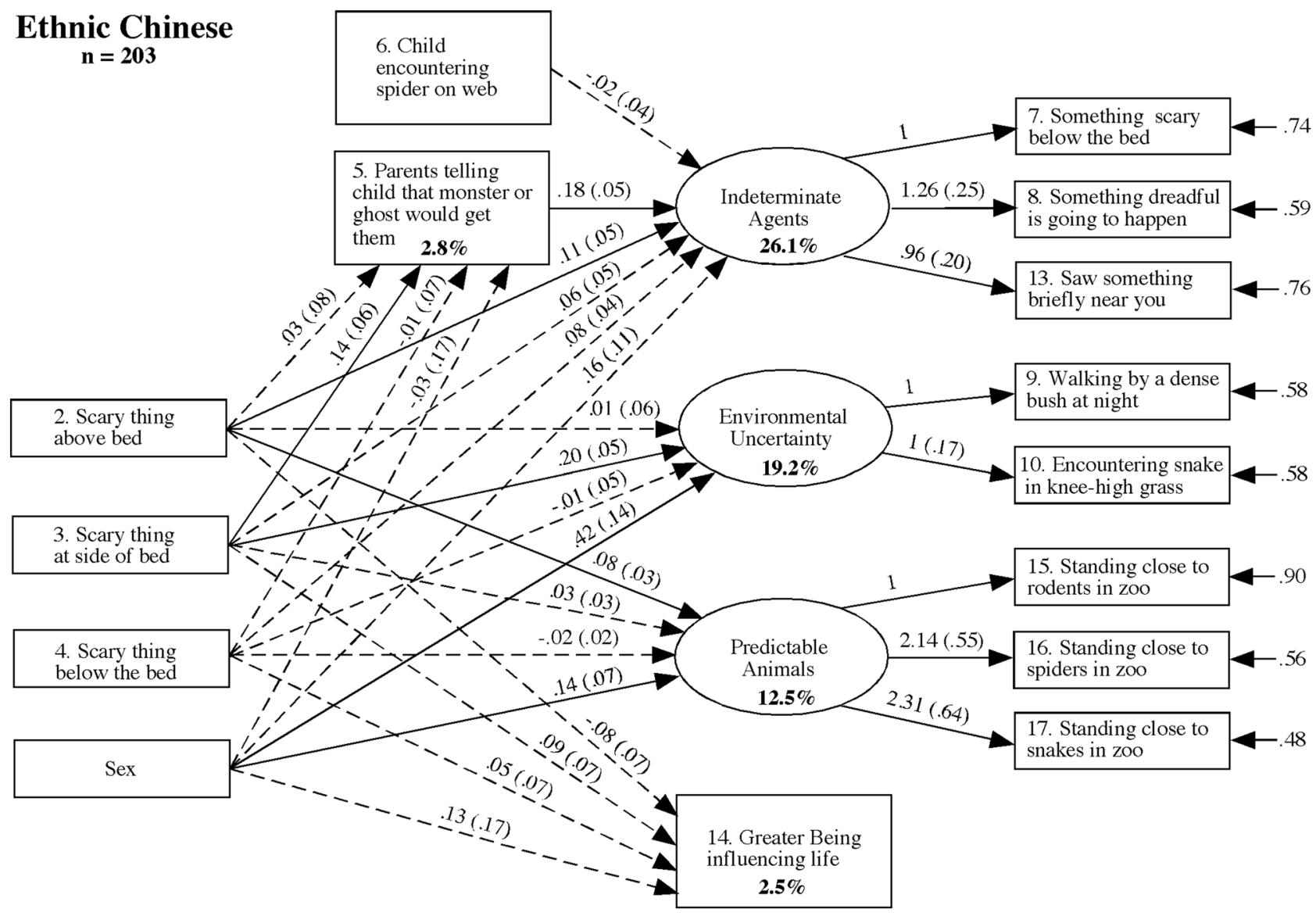

Fig. 7 Structural equation model of ethnic Chinese illustrating the pathways of influence of predictor variables (childhood fear of spiders and the spatial aspects of childhood nighttime fears of a scary thing relative to the bed) and the mediating variable of familial

better nighttime vision. In nonhuman primates that are preyed upon by nocturnal predators, such as leopards, such anticipation is expressed by the choice of sleeping sites high in trees near crown edges and in daytime by prolonged vigilance after a model felid predator is detected and then disappears from view (cf. Caine, 1984; Coss \& Ramakrishnan, 2000; Coss et al., 2005; Dorn, 2009). This antipredator system assessing potential yet uncertain threats appears to exhibit cognitive properties that parallel the widespread belief in supernatural agents in humans (Atran, 2002; Lemert, 1997); we argue that this parallel property reflects a similar mental-assessment process invoked in both circumstances by the common evocative properties of powerful or controlling entities that are unseen, although their presences are somehow felt. More specifically, the belief in supernatural agencies might be caused by the need to explain and control ambiguous and anxiety-provoking outcomes. And, this hypothesis has been further supported by empirical studies in which researchers found that individuals with low tolerance of ambiguity have higher fearfulness of the paranormal, which further predicts threats on adult fears. Solid paths depict statistically significant influences, with $p<0.05$, two-tailed. Standardized path coefficients with standard errors in parentheses are shown next to the pathways

higher beliefs in the paranormal (Lange \& Houran, 1998, 1999). Concordant with this view, Atran (2002, p. 78) also argues that religiosity is the evolutionary by-product of the "predator-protector-prey detection schema" (also see Atran $\&$ Norenzayan, 2004). However, with respect to the association of childhood nighttime fear and the belief in a Greater Being, the Vietnamese did not show this association unlike the ethnic Chinese even though both ethnic groups consisted of individuals with strong spiritual beliefs. Confidence in this ethnic-group difference, however, is limited because influence of a greater being is only a single-response item. A similar cross-cultural difference for spatial nighttime fear is also apparent in research by Hunt (1997) who found that Africans who believe in more varied evil spirits than do Europeans (e.g., Ngulube, 1989) were the most fearful at night.

Similar to the ambiguity generated by darkness, this conception that something is lurking out there can be magnified by views obstructed by vegetation, as is apparent in both ethnic groups by the association of childhood nighttime fear and the latent variable, environmental uncertainty (Figs. 4 
and 5). More specifically among the individuals of both ethnic groups who exhibited childhood nighttime fear, only the fear of something scary from the side location was a reliable predictor of environmental uncertainty (Figs. 6 and 7), a latent variable consisting of potential lateral threats. These associations contrast with the absences of the associations between the fear of something scary from the side location and indeterminate agents; these associations also contrast with the absences of the associations between the fear of something scary from the side location and the belief in a Greater Being. This context of perceived obstruction of viewing possible threats is entirely different from that of unseen ethereal and encompassing threats not obscured by physical structures. Such a distinction is indicated in both ethnic groups (Table 1) by the low correlations of indeterminate agents (factor 1) and environmental uncertainty (factor 2). In short, the common component of the influence of childhood nighttime fear on these latent variables is the sense that something dangerous could be lurking nearby; but they differ in the possible passive role of awaiting a potential attack from the perspective of the bed (indeterminate agents) or the active role of choosing how to navigate dangerous terrain to avoid potential attack (environmental uncertainty).

In contrast to this context of unseen threats, when potentially dangerous animals are in full view while secured behind a safe barrier as in zoo exhibits, the association virtually disappears between childhood nighttime fear and predictable animals, the latent variable consisting of small rodents, snakes, and spiders in safe zoo exhibits (Figs. 4 and 5). However, an unexpected finding emerged when structural equation modeling was restricted to only those ethnic Chinese who exhibited childhood nighttime fear (Fig. 7); these participants showed a reliable association of something scary above the bed and viewing these animals in zoo exhibits.

Although the childhood nighttime fear that consist of imagined threats exhibited a reliable influence on the latent variable, indeterminate agents, the childhood fear of spiders showed no such properties (Figs. 4, 5, 6, and 7), even though the fear of spiders was higher than that of nighttime fear. The absence of this association between fear of spiders in childhood and indeterminate agents is contrary to our hypothesis. In retrospect, it seemed reasonable to make the prediction, based on factor-analytic evidence linking spiders to ghosts (Scherer \& Nakamura, 1968), that spiders might be perceived in a manner similar to that of the unseen threats characterized by indeterminate agents. Yet, evidence in our study that spiders are perceived differently suggests that the ability to pinpoint the absolute location of something dangerous, compared to something known to be present but unseen, engenders different affective states and defensive decision-making. In addition, the absence of a reliable relationship between childhood nighttime fear and predictable animals remembered in safe zoo exhibits reflects these different affective states. Although there were no significant interactions between ethnic groups and sex and remembered feelings of discomfort when encountering spiders on webs in childhood, the percentages of individuals feeling very uncomfortable were among the highest generated by our survey, a finding consistent with previous research on children (e.g., Merckelbach et al., 1996; Lane \& Gullone, 1999). The absence of sex differences in our study contrasts with research that showed that girls ranked spiders as more fearful than did boys (e.g., ), a result that likely reflects differences in the urgency of our question which involve imagining a sudden encounter with a spider on a web as a child.

\section{Cultural Implications of Evolutionarily Old Spatial Fears}

The latent variable, indeterminate agents, approximates a construct with ghost-like properties because it embodies assessment of possible danger from something unseen lurking nearby as a sensed presence (cf. Cheyne, 2001; Suedfeld \& Mocellin, 1987). As an epilog to our study, the fear of ghosts has broad cultural implications because it affects both physical design and storytelling in literature and film. As noted above, the fear of ghosts and evil spirits permeates Vietnamese and Chinese folkpsychology (reviewed by Bertrand, 1996; Clark \& Winslett, 2011; Livo \& Cha, 1991; Thinh, 2006), and conceptions of spiritual threats from specific directions can influence the spatial layout of communities and residential architecture. In particular, contemporary Chinese architecture often incorporates the historical tradition of feng shui in which malevolent spirits are believed to attack people directly in straight lines that can be deflected by winding pathways and curving walls (Lai, 1974). Also, the belief in malevolent ghosts and other supernatural entities is sufficiently prevalent in the contemporary life of East Asians that it can impact travel plans to tsunami-affected resorts where people had died (Rittichainuwat, 2011).

Assessment of imagined spirits attacking from specific directions also implies that these invisible agents monitor their victims prior to attacking in a manner analogous to how predators ambush prey from cover in a real-world context. Ambushing is effective because the element of surprise diminishes the time frame for prey to orient appropriately to engage predators defensively and chose escape routes (see Courbin et al., 2016). Moreover, settings replete with vegetation and rock outcrops that afford predator concealment engender in prey patterns of spatially distributed wariness in what has been called the "landscape of fear" (Laundré et al., 2010 , p. 2). The contextual assessment of the likelihood of being ambushed with limited opportunities to escape could include the conceptualization that something unseen 
is watching to enable its attack (for humans, see Conty et al., 2010). The process of being watched and inferences of potential consequences is viewed as a strong contributing component of the imagined capabilities of supernatural agents (Shariff \& Norenzayan, 2007). Human ancestors have had a long history of ambushing prey as a hunting tactic in areas with restricted pathways for prey escape (Kübler et al., 2015). Such ambush-hunting tactics could have been intuitively derived from the even longer history in which hominins as prey were very attentive to potential threats in certain settings and engaged in appropriate refuge-seeking behavior (Treves \& Naughton-Treves, 1999; Coss \& Moore, 2002; Coss, 2021).

As alluded to earlier, our field observations of monkeys selecting sleeping trees at sunset to avoid leopards and pythons (Ramakrishnan \& Coss, 2000, 2001) revealed an uncanny attribution that these monkeys expected to encounter something dreadful if they remained on the ground. For contemporary humans in the African bush, such fear of ground-level threats at sunset, especially near water, reflects real endangerment by lions and hippopotamuses (Packer et al., 2011; Penkunas et al., 2014). A similar assertion of the emergence of fear was made by Mathias Clasen (2012, p. 223) in his discussion of the literary dynamics of horror fiction:

Modern-day horror stories, by flinging us into virtual universes that brim with lurking dangers and aggressive predators, send us on a journey backward in time, to the dark days in human phylogeny when the setting sun signified grave danger and real monsters could very well be gathering just outside the fragile circle of light cast by the bonfire".

Expressions of nighttime fears in bed are similarly anticipatory and can be primed by watching frightening films (Cantor, 2004, p. 288). Forewarning readers and viewers that a horrific event is going to occur intensifies their fear when the event unfolds in literature and film (see Cantor, 2004). The uncertainty of being ambushed in a confined spacecraft setting was best exemplified by the 1979 science-fiction film Alien (directed by Ridley Scott). Its 2017 sequel, Alien: Covenant (also directed by Ridley Scott), included predatory attacks in open and confined areas in sequences critiqued as the "canny management of expectations" (Scott, 2017).

Outside of their portrayal in horror films, it is not difficult to envision how different cultures would generalize real ground-level threats at night to include malevolent spiritual entities. Atran and Norenzayan (2004) argue that various religions exploit an evolved agency detector as a component of the "Theory of Mind." Beliefs in supernatural agents can encompass punishers, benevolent protectors, and menacing lurkers. Deified protectors are often construed as having human form (Guthrie, 1993; Boyer, 1996, p. 87; Clark $\&$ Winslett, 2011). Such anthropomorphic properties of an influential protector spirit might explain, in retrospect, the unpredicted disassociations of the single-item influence of a greater being and the above, side, and below locations of something scary at night with its menacing properties.

\section{Conclusion}

Our modeling of different pathways showing the absence of influence of fear of spiders in childhood and the reliable influence of children's nighttime fear on the adult perception of apparitions, fear of unspecific threats, and fear of something scary below the bed suggests that the expression of this type of adult fear reflects the developmental continuity of phylogenetically old and important cognitive processes. With respect to nighttime fear, the relative continuity from childhood to adulthood is complemented by negative information from adults. One hypothesis of the adaptive function of language is the transfer of knowledge of dangerous situations to children (Williams, 1966, p. 15). It is conceivable that threatening children to behave using scary referents has more universal properties shaping adult fears than that shown herein. Future cross-cultural research should examine similar parental practices that might influence children's fears as well as promote the development of vigilance patterns (Wirtz \& Wawra, 1986) and some phobias in older individuals. To truly understand these mediating relationships, one would require longitudinal data. Despite evidence that the frequency of children reporting a nighttime fear of scary things is similar to that of adult remembrances of the same childhood fears (cf. Gordon et al., 2007, p. 99; Coss, 2021), our results could still be biased due to the retrospective reporting of childhood experiences. Finally, cross-cultural research conducted in the field is constrained by the interviewer-administration process that can include response fatigue for long questionnaires (Choi \& Pak, 2005, p. 7). With respect to further study of our topic, a more elaborate investigation of the cognitive properties of sensed presences in an evolutionary context would benefit from a greater number of correlated questions to derive meaningful latent variables.

Data Availability An Excel file with data will be deposited to an openscience platform.

Code Availability A Word file with Excel codes will be deposited to an open-science platform.

\section{Declarations}

Consent to Participate Adult participants signed permission forms. 
Consent for Publication The authors grant the publisher permission to publish this.

Competing Interests The authors declare no competing interests.

Open Access This article is licensed under a Creative Commons Attribution 4.0 International License, which permits use, sharing, adaptation, distribution and reproduction in any medium or format, as long as you give appropriate credit to the original author(s) and the source, provide a link to the Creative Commons licence, and indicate if changes were made. The images or other third party material in this article are included in the article's Creative Commons licence, unless indicated otherwise in a credit line to the material. If material is not included in the article's Creative Commons licence and your intended use is not permitted by statutory regulation or exceeds the permitted use, you will need to obtain permission directly from the copyright holder. To view a copy of this licence, visit http://creativecommons.org/licenses/by/4.0/.

\section{References}

Agresti, A. (2002). Categorical data analysis (2nd ed.). Wiley.

Anderson, J. R. (1984). Ethology and ecology of sleep in monkeys and apes. Advances in the Study of Behavior, 14, 165-229. https:// doi.org/10.1016/S0065-3454(08)60302-2

Armfield, J. M. (2006). Cognitive vulnerability: A model of the ethiology of fear. Clinical Psychology Review, 26(6), 746-768. https:// doi.org/10.1016/j.cpr.2006.03.007

Arrindell, W. A., Pickersgill, M. J., Merckelbach, H., Ardon, A. M., \& Cornet, F. (1991). Phobic dimensions: III. Factor analytic approaches to the study of common phobic fears; an updated review of findings obtained with adult subjects. Advances in Behavioural Research and Therapy, 13(2), 73-130. https://doi. org/10.1016/0146-6402(91)90014-2

Atran, S. (2002). In Gods we trust: The evolutionary landscape of religion. Oxford University Press.

Atran, S., \& Norenzayan, A. (2004). Religion's evolutionary landscape: Counterintuition, commitment, compassion, communion. Behavioral and Brain Sciences, 27(6), 713-730. https://doi.org/10. 1017/S0140525X04000172

Baker, J. O., \& Bader, C. D. (2014). A social anthropology of ghosts in twenty-first-century America. Social Compass, 61(4), 569-593. https://doi.org/10.1177/0037768614547337

Bamber, J. H. (1974). The fears of adolescents. The Journal of Genetic Psychology, 125(2), 127-140. https://doi.org/10.1080/00221325. 1974.10532310

Bauer, D. H. (1976). An exploratory study of developmental changes in children's Fears.

Beaudet, D. (1991). Encountering the monster in children's dreams: Combat, taming, and engulfment. Quadrant, 24, 65-73.

Benet-Martínez, V., \& Karakitapoğlu-Aygün, Z. (2003). The interplay of cultural syndromes and personality in predicting life satisfaction: Comparing Asian Americans and European Americans. Journal of Cross-Cultural Psychology, 34(1), 38-60. https:// doi.org/10.1177/0022022102239154

Bertrand, D. (1996). The Thầy: masters in Huế, Vietnam. Asian Folklore Studies, 55(2), 271-286. http://www.jstor.org/stable/1178822

Blum, S. H. (1976). Some aspects of belief in prevailing superstitions. Psychological Reports, 38(2), 579-582. https://doi.org/10.2466/ pr0.1976.38.2.579

Blumstein, D. T. (2002). Moving to suburbia: Ontogenetic and evolutionary consequences of life on predator-free islands. Journal of Biogeography, 29(5-6), 685-692. https://doi.org/10.1046/j. 1365-2699.2002.00717.x
Browne, M. W., \& Robert Cudeck, R. C. (1992). Alternative ways of assessing model fit. Sociological Methods \& Research, 21(2), 230-258. https://doi.org/10.1177/0049124192021002005? journalCode $=$ smra

Boyer, P. (1996). What makes anthropomorphism natural: intuitive ontology and cultural representations. Journal of the Royal Anthropological Institute, 2, 1-15. http://www.jstor.org/stable/ 3034634

Burnham, J. J., \& J. J., \& Gullone, E. (1997). The fear survey schedule for children-II: A psychometric investigation with American data. Behaviour Research and Therapy, 35(2), 165-173. https://doi.org/10.1016/S0005-7967(96)00089-7.

Cantor, J. (2004). I'll never have a clown in my house - why movie horror lives on. Poetics Today, 25(2), 283-304. https://doi.org/ $10.1215 / 03335372-25-2-283$

Cheyne, J. A. (2001). The ominous numinous. Sensed presence and 'other' hallucinations. Journal of Consciousness Studies, 8(5-7), 133-150.

Choi, B. C. K., \& Pak, A. W. P. (2005). A catalog of biases in questionnaires. Preventing Chronic Disease, 2(1), A13. https:// www.cdc.gov/pcd/issues/2005/jan/04_0050.htm

Clarke, D. (1991). Belief in the paranormal: a New Zealand survey. Journal of the Society for Psychical Research, 57, 412-425. http://psycnet.apa.org/psycinfo/1991-30096-001.

Clark, K. J., \& Winslett, J. T. (2011). The evolutionary psychology of Chinese religion: Pre-Qin high Gods as punishers and rewarders. Journal of the American Academy of Religion, 79(4), 928-960. https://doi.org/10.1093/jaarel/lfr018

Clasen, M. (2012). Monsters evolve: A biocultural approach to horror stories. Review of General Psychology, 16(2), 222-229. https:// doi.org/10.1037/a0027918

Conty, L., Gimmig, G., Belletier, C., George, N., \& Huguet, P. (2010). The cost of being watched: Stroop interference increases under concomitant eye contact. Cognition, 115(1), 133-139. https:// doi.org/10.1016/j.cognition.2009.12.005

Coss, R. G. (1991). Context and animal behavior III: The relationship between early development and evolutionary persistence of ground squirrel antisnake behavior. Ecological Psychology, 3(4), 277-315. https://doi.org/10.1207/s15326969eco0304_1

Coss, R. G. (1999). Effects of relaxed natural selection on the evolution of behavior. In S. A. Foster \& J. A. Endler (Eds.), Geographic variation in behavior: Perspectives on evolutionary mechanisms (pp. 180-208). Oxford University Press.

Coss, R. G. (2003). The role of evolved perceptual biases in art and design. In E. Voland \& K. Grammer (Eds.), Evolutionary aesthetics (pp. 69-130). Springer-Verlag.

Coss, R. G., \& Charles, E. P. (2004). The role of evolutionary hypotheses in psychological research: Instincts, affordances, and relic sex differences. Ecological Psychology, 16(3), 199-236. https:// doi.org/10.1207/s15326969eco1603_3

Coss, R. G. (2021). Something scary is out there: Remembrances of where the threat was located by preschool children and adults with nighttime fear. Evolutionary Psychological Science. https:// doi.org/10.1007/s40806-021-00279-9

Coss, R. G., \& Goldthwaite, R. O. (1995). The persistence of old designs for perception. In N. S. Thompson (Ed.), Perspectives in ethology 11: Behavioral design (pp. 83-148). Plenum Press.

Coss, R. G., \& Moore, M. (2002). Precocious knowledge of trees as antipredator refuge in preschool children: An examination of aesthetics, attributive judgments and relic sexual dinichism. Ecological Psychology, 14(4), 181-222. https://doi.org/10.1207/ S15326969ECO1404_1

Coss, R. G., \& Penkunas, M. J. (2016). Sex difference in choice of concealed or exposed refuge sites by preschool children viewing a model leopard in a playground simulation of antipredator behavior. International Journal of Psychological Research, 9(2), 8-19. https://doi.org/10.21500/20112084.2325 
Coss, R. G., \& Ramakrishnan, U. (2000). Perceptual aspects of leopard recognition by wild bonnet macaques (Macaca radiata). Behaviour, 137(3), 315-335. https://doi.org/10.1163/156853900502105

Coss, R. G., Ramakrishnan, U., \& Schank, J. (2005). Recognition of partially concealed leopards by wild bonnet macaques (Macaca radiata): The role of the spotted coat. Behavioural Processes, 68(2), 145-163. https://doi.org/10.1016/j.beproc.2004.12.004

Courbin, N., Loveridge, A. J., Macdonald, D. W., Fritz, H., \& Valeix, M. (2016). Reactive responses of zebras to lion encounters shape their predator-prey space game at large scale. Oikos, 125(6), 829-838. https://doi.org/10.1111/oik.02555

Darwin, C. (1877). A biographical sketch of an infant. Mind, 2(7), 285-294. http://www.jstor.org/stable/2246907

Davey, G. C. L. (1995). Preparedness and phobias: Specific evolved associations or a generalized expectancy bias? The Behavioral and Brain Sciences, 18(2), 289-325. https://doi.org/10.1017/ S0140525X00038498

Davey, G. C. L., Forster, L., \& Mayhew, G. (1993). Familial resemblances in disgust sensitivity and animal phobias. Behaviour Research and Therapy, 31(1), 41-50. https://doi.org/10.1016/ 0005-7967(93)90041-R

Davidson, P. M., White, P. N., Smith, D. J., \& Poppen, W. A. (1989). Content and intensity of fears in middle childhood among rural and urban boys and girls. The Journal of Genetic Psychology, 150(1), 51-58. https://doi.org/10.1080/00221325.1989.9914574

Deacon, T. W. (2016). On human (symbolic) nature: how the word became flesh. In G. Etzelmüller \& C. Tewes (Eds.), Embodiment in evolution and culture (pp. 129-150).Tübingen, Germany: Mohr Siebeck.

Dong, Q., Bin Yang, B., \& Ollendick, T. H. (1994). Fears in Chinese children and adolescents and their relations to anxiety and depression. Journal of Child Psychology and Psychiatry, 35(2), 351-363. https://doi.org/10.1111/j.1469-7610.1994.tb01167.x

Doran, D. M. (1993). Sex differences in adult chimpanzee positional behavior: The influence of body size on locomotion and posture. American Journal of Physical Anthropology, 91(1), 99-115. https://doi.org/10.1002/ajpa.1330910107

Doran, D. M., \& Hunt, K. D. (1994). Comparative locomotor behavior of chimpanzees and bonobos. In R. W. Wrangham, W. C. McGrew, F. B. M. de Waal, \& P. G. Heltne (Eds.), Chimpanzee cultures (pp. 93-108). Harvard University Press.

Dorn, L. (2009). Assertive antipredator behavior by feral horse stallions (Equus caballus): predator recognition, tonic vigilance and group defense. Ph.D. Dissertation, University of California, Davis. ProQuest Publication 3375496.

Earls, F. (1980). Prevalence of behavior problems in 3-year-old children: A cross-national replication. Archives of General Psychiatry, 37, 1153-1157. https://doi.org/10.1001/archpsyc.1980.01780230071010

Evans, A. R., Jones, D., Boyer, A., Brown, J. H., Costa, D. P., Ernest, S. K. M., \& Uhen, M. D. (2019). The maximum rate of mammalian evolution. Proceedings of the National Academy of Sciences USA, 109(11), 4187-4190. https://doi.org/10.1073/pnas.1120774109

Farley, F. H., Cohen, A., Goldberg, J., \& Yinon, Y. (1978). Fears in American and Israeli women. The Journal of Social Psychology, 106(1), 17-24. https://doi.org/10.1080/00224545.1978.9924141

Ferrari, M. (1986). Fears and phobias in childhood: some clinical and developmental considerations. Child Psychiatry and Human Development, 17(2), 75-87. https://doi.org/10.1007/BF00706646

Field, A. P., \& Lawson, J. (2003). Fear information and the development of fears during childhood: Effects on implicit fear responses and behavioural avoidance. Behaviour Research and Therapy, 41(11), 1277-1293. https://doi.org/10.1016/S0005-7967(03)00034-2.

Fonseca, A. C., Yule, W., \& Erol, N. (1994). Cross-cultural issues. In T. H. Ollendick, N. J. King, \& W.Yule (Eds.), International handbook of phobic and anxiety disorders in children and adolescents (pp. 67-84). New York: Springer Science+Business Media, LLC. https://doi.org/10.1007/978-1-4899-1498-9
Fredrikson, M., Annas, P., Fischer, H., \& Wik, G. (1996). Gender and age differences in the prevalence of specific fears and phobias. Behaviour Research and Therapy, 34(1), 33-39. https://doi.org/ 10.1016/0005-7967(95)00048-3

Fruth, B., \& Hohmann, G. (1994). Comparative analyses of nest-building behavior in bonobos and chimpanzees. In R. W. Wrangham, W. C. McGrew, F. B. M. de Waal, \& P. G. Heltne (Eds.), Chimpanzee Cultures (pp. 109-128). Harvard University Press.

Gerull, F. C., \& Rapee, R. M. (2002). Mother knows best: Effects of maternal modelling on the acquisition of fear and avoidance behaviour in toddlers. Behaviour Research and Therapy, 40(3), 279-287. https://doi.org/10.1016/S0005-7967(01)00013-4

Goldthwaite, R. O., Coss, R. G., \& Owings, D. H. (1990). Evolutionary dissipation of an antisnake system: Differential behavior by California and Arctic ground squirrels in above- and below-ground contexts. Behaviour, 112(3/4), 246-269.

Gordon, A. D., Green, D. J., \& Richmond, B. G. (2008). Strong postcranial size dimorphism in Australopithecus afarensis: Results from two new resampling methods for multivariate data sets with missing data. American Journal of Physical Anthropology, 135(3), 311-328. https://doi.org/10.1002/ajpa.20745

Gordon, J., \& King, N. (2002). Children's night-time fears: An overview. Counselling Psychology Quarterly, 15(2), 121-132. https:// doi.org/10.1080/09515070110104097

Gordon, J., King, N., Gullone, E., Muris, P., \& Ollendick, T. H. (2007). Treatment of children's nighttime fears: The need for a modern randomized controlled trial. Clinical Psychology Review, 27(1), 98-113. https://doi.org/10.1016/j.cpr.2006.07.002

Grabowski, M., Hatala, K. G., Jungers, W. L., \& Richmond, B. G. (2015). Body mass estimates of hominin fossils and the evolution of human body size. Journal of Human Evolution, 85, 75-93. https://doi.org/10.1016/j.jhevol.2015.05.005

Gullone, E. (2000). The development of normal fear: A century of research. Clinical Psychology Review, 20(4), 429-451. https:// doi.org/10.1016/S0272-7358(99)00034-3

Guthrie, S. E. (1993). Faces in the clouds, a new theory of religion. Oxford University Press.

Haas, R., Watson, J., Buonasera, T., Southon, J., Chen, J. C., Noe, S., \& Parker, G. (2020). Female hunters of the early Americas. Science Advances, 6(45), eabd0210. https://doi.org/10.1126/sciadv.abd0310

Hall, G. S. (1897). A study of fears. The American Journal of Psychology, 8(2), 147-249. http://www.jstor.org/stable/1410940

Halliday, J., \& McNaughton, S. (1982). Sex differences in play at kindergarten. New Zealand Journal of Education Studies, 17(2), 161-170.

Hallowell, A. I. (1938). Fear and anxiety as cultural and individual variables in a primitive society. The Journal of Social Psychology, 9(1), 25-47. https://doi.org/10.1080/00224545.1938.9921672

Halpern, D. L., Blake, R., \& Hillenbrand, J. (1986). Psychoacoustics of a chilling sound. Perception \& Psychophysics, 39(2), 77-80. https://doi.org/10.3758/BF03211488

Haraldsson, E. (1985). Representative national surveys of psychic phenomena: Iceland, Great Britain, Sweden, USA and Gallup's Multinational Survey. Journal of the Society for Psychical Research, 53(801), 145-158.

Hart, D., \& Sussman. R. W. (2008). Man the hunted: primates, predators, and human evolution, Expanded Edition. Westview press.

Hartmann, E. (1984). The nightmare: The psychology and biology of terrifying dreams. Basic Books.

Herskovits, M. J. (1951). Man and his works. Alfred A. Knopf.

Hunt, C. B. (1997). A Cross-cultural examination of daytime and nighttime fears as evolved adaptive mechanisms. Master's Thesis, California State University, Sacramento, California.

Inglehart, R. (2004). Human beliefs and values: A cross-cultural sourcebook based on the 1999-2002 values surveys. Siglo Veintiuno Editores, Mexico, D. F. 
Jungers, W. L. (1982). Lucy's limbs: Skeletal allometry and locomotion in Australopithecus afarensis. Nature, 297, 676-678. https://doi. org/10.1038/297676a0

Kappelman, J., Ketcham, R. A., Pearce, S., Todd, L., Akins, W., Colbert, M. W., \& Witzel, A. (2016). Perimortem fractures in Lucy suggest mortality from fall out of tall tree. Nature, 537, 503-507. https:// doi.org/10.1038/nature19332

Kendler, K. S., Neale, M. C., Kessler, R. C., Heath, A. C., \& Eaves, L. J. (1992). The genetic epidemiology of phobias in women: The interrelationship of agoraphobia, social phobia, situational phobia, and simple phobia. Archives of General Psychiatry, 49(4), 273-281. https://doi.org/10.1001/archpsyc.1992.01820040025003

Kimura, D. (1996). Sex, sexual orientation and sex hormones influence human cognitive function. Current Opinion in Neurobiology, 6(2), 259-263. https://doi.org/10.1016/S0959-4388(96)80081-X

King, N. J., Gullone, E., \& Ollendick, T. H. (1998). Etiology of childhood phobias: Current status of Rachman's three pathways theory. Behaviour Research and Therapy, 36(3), 297-309. https:// doi.org/10.1016/S0005-7967(98)00015-1

King, N. J., Hamilton, D. I., \& Ollendick, T. H. (1988). Children's phobias: a behavioural perspective. New York: John Wiley \& Sons. http://trove.nla.gov.au/version/45415581

King, N. J., Ollendick, T. H., \& Tonge, B. J. (1997). Children's nighttime fears. Clinical Psychological Review, 17(4), 431-443. https://doi.org/10.1016/S0272-7358(97)00014-7

Kirkpatrick, D. R. (1984). Age, gender and patterns of common intense fears among adults. Behaviour Research and Therapy, 22(2), 141-150. https://doi.org/10.1016/0005-7967(84)90102-5

Kleinknecht, R. A. (2002). Comments on: Non-associative fear acquisition: A review of the evidence from retrospective and longitudinal research. Behaviour Research and Therapy, 40(2), 159-163. https://doi.org/10.1016/S0005-7967(01)00047-X

Klingman, A., \& Wiesner, E. (1982). The relationship of proximity to tension areas and size of settlement to fear levels of Israeli children. Journal of Behavior Therapy and Experimental Psychiatry, 13(4), 321-323. https://doi.org/10.1016/0005-7916(82)90077-5

Klingman, A., \& Wiesner, E. (1983). Analysis of Israeli children's fears: a comparison of religious and secular communities. International Journal of Social Psychiatry, 29(4), 269-274. https:// doi.org/10.1177/002076408302900406

Kraft, T. S., Venkataraman, V. V., \& Dominy, N. J. (2014). A natural history of human tree climbing. Journal of Human Evolution, 71(6), 105-118.

Kübler, S., Owenga, P., Reynolds, S. C., Rucina, S. M., \& King, G. C. P. (2015). Animal movements in the Kenya Rift and evidence for the earliest ambush hunting by hominins. Scientific Reports, 5, 14011. https://doi.org/10.1038/srep14011

Lahti, D. C., Johnson, N. A., Ajie, B. C., Otto, S. P., Hendry, A. P., Blumstein, D. T., \& Foster, S. A. (2009). Relaxed selection in the wild: Contexts and consequences. Trends in Ecology and Evolution, 24(9), 487-496. https://doi.org/10.1016/j.tree.2009.03.010

Lai, C.Y.D. (1974). A feng shui model as a location index. Annals of the Association of American Geographers, 54(4), 506-513. https://doi.org/10.1111/j.1467-8306.1974.tb00999.x

Li, C., Yang, X., Ding, Y., Zhang, L., Fang, H., Tang, S., \& Jiang, Z. (2011). Do Père David's deer lose memories of their ancestral predators? PLOS ONE, 6(8), e23623. https://doi.org/10.1371/ journal.pone.0023623

Lockwood, C. A., Richmond, B. G., Jungers, W. L., \& Kimbel, W. H. (1996). Randomization procedures and sexual dimorphism in Australopithecus afarensis. Journal of Human Evolution, 31(6), 537-548. https://doi.org/10.1006/jhev.1996.0078

Lane, B., \& Gullone, E. (1999). Common fears: A comparison of adolescents' self-generated and fear survey schedule generated fears. The Journal of Genetic Psychology, 160(2), 194-204. https://doi.org/10.1080/00221329909595392
Lange, R., \& Houran, J. (1998). Delusions of the paranormal: a haunting question of perception. The Journal of Nervous and Mental Disease, 186(10), 637-645. http://journals.lww.com/jonmd/Abstract/1998/ 10000/Delusions_of_the_Paranormal_A_Haunting_Question.8. aspx.

Lange, R., \& Houran, J. (1999). The role of fear in delusions of the paranormal. The Journal of Nervous and Mental Disease, 187(3), 159-166. http://journals.lww.com/jonmd/Abstract/1999/03000/ The_Role_of_Fear_in_Delusions_of_the_Paranormal.5.aspx.

Langergraber, K. E., Prüfer, K., Rowney, C., Boesch, C., Crockford, C., Fawcett, K., \& Vigilant, L. (2012). Generation times in wild chimpanzees and gorillas suggest earlier divergence times in great ape and human evolution. Proceedings of the National Academy of Sciences USA, 109(39), 15716-15721. https://doi. org/10.1073/pnas.1211740109

Lapouse, R., \& Monk, M. A. (1958). An epidemiologic study of behavior characteristics in children. American Journal of Public Health, 48(9), 1134-1144

Laundré, J. W., Hernandez, L., \& Ripple, W. J. (2010). The landscape of fear: Ecological implications of being afraid. The Open Ecology Journal, 3, 1-7. https://doi.org/10.2174/1874213001003030001

Lee, D. S., \& Kang, H. R. (2012). The categorization of "bad animal" and its relation to animal appearances: A study of 6-year-old children's perceptions. Journal of Social, Evolutionary, and Cultural Psychology, 6(1), 32-49. https://doi.org/10.1037/h0099226

Lemert, E. M. (1997). The trouble with evil: Social control at the edge of morality. State University of New York Press.

Livo, N. J., \& Cha, D. (1991). Folk stories of the Hmong: Peoples of Laos, Thailand, and Vietnam. Libraries Unlimited, Greenwood Publishing Group Inc.

LoBue, V., \& DeLoache, J. S. (2010). Superior detection of threat-relevant stimuli in infancy. Developmental Science, 13(1), 221-228. https:// doi.org/10.1111/j.1467-7687.2009.00872.x

Marks, I. (2002). Innate and learned fears are at opposite ends of a continuum of associability. Behaviour Research and Therapy, 40(2), 165-167. https://doi.org/10.1016/S0005-7967(01)00048-1

Marks, I., \& Tobena, A. (1990). Learning and unlearning fear: A clinical and evolutionary perspective. Neuroscience \& Biobehavioral Reviews, 14(4), 365-384. https://doi.org/10.1016/S01497634(05)80059-4

Masao, F. T., Ichumbaki, E. B., Cherin, M., Barili, A., Boschian, G., Iurino, D. A., \& Manzi, G. (2016). New footprints from Laetoli (Tanzania) provide evidence for marked body size variation in early hominins. eLife, 5, e19568. https://doi.org/10.7554/eLife.19568

McHenry, H. M. (1992). Body size and proportions in early hominids. American Journal of Physical Anthropology, 87(4), 407-431. https://doi.org/10.1002/ajpa.1330870404

McLean, C. Y., Reno, P. L., Pollen, A. A., Bassan, A. I., Capellini, T. D., Guenther, C., \& Kingsley, D. M. (2011). Human-specific loss of regulatory DNA and the evolution of human-specific traits. Nature, 471, 216-219. https://doi.org/10.1038/nature09774

McNally, R. J. (2002). On nonassociative fear emergence. Behaviour Research and Therapy, 40(2), 169-172. https://doi.org/ 10.1016/S0005-7967(01)00049-3

Merckelbach, H., Muris, P., \& Schouten, E. (1996). Pathways to fear in spider phobic children. Behaviour Research and Therapy, 34(11-12), 935-938. https://doi.org/10.1016/S0005-7967(96) 00052-6

Mineka, S., \& Öhman, A. (2002). Born to fear: Non-associative vs associative factors in the etiology of phobias. Behaviour Research and Therapy, 40(2), 173-184. https://doi.org/10.1016/ S0005-7967(01)00050-X

Moorjani, P., Amorim, C. E. G., Amdt, P. F., \& Przeworski, M. (2016). Variation in the molecular clock of primates. Proceedings of the National Academy of Sciences USA, 113(38), 10607-10612. https:// doi.org/10.1073/pnas.1600374113 
Morris, R. J., \& Kratochwill, T. R. (1983). Treating children's fears and phobias: A behavioral approach. Pergamon Press.

Muris, P., Bodden, D., Merckelbach, H., Ollendick, T. H., \& King, N. (2003). Fear of the beast: A prospective study on the effects of negative information on childhood fear. Behaviour Research and Therapy, 41(2), 195-208. https://doi.org/10.1016/S00057967(01)00137-1

Muris, P., Meesters, C., Merckelbach, H., Verschuren, M., Geebelen, E., \& Aleva, E. (2002a). Fear of storms and hurricanes in Antillean and Belgian children. Behaviour Research and Therapy, 40(4), 459-469. https://doi.org/10.1016/S0005-7967(01)00058-4

Muris, P., Merckelbach, H., \& Collaris, R. (1997a). Common childhood fears and their origins. Behaviour Research and Therapy, 35(10), 929-937. https://doi.org/10.1016/S0005-7967(97)00050-8

Muris, P., Merckelbach, H., Meesters, C., \& Van Lier, P. (1997b). What do children fear most often? Journal of Behavior Therapy and Experimental Psychiatry, 28(4), 263-267. https://doi.org/10. 1016/S0005-7916(97)00024-4

Muris, P., Merckelbach, H., Ollendick, T. H., King, N. J., Meesters, C., \& van Kessel, C. (2002b). What is the revised fear survey schedule for children measuring? Behaviour Research and Therapy, 40(11), 1317-1326. https://doi.org/10.1016/S0005-7967(02)00007-4

Muthén, L. K., \& Muthén, B. (1998). Mplus, the comprehensive modeling program for applied researchers user's guide. Los Angles, CA: Muthén \& Muthén.

Myers, K. M., Croake, J. W., \& Singh, A. (1987). Adult fears of four ethnic groups: Whites, Chinese, Japanese, and "boat people". The International Journal of Social Psychiatry, 33(1), 56-67. https://doi.org/10.1177/002076408703300109

Ngulube, N. M. J. (1989). Some aspects of growing up in Zambia. Lusaka, Zambia: Kenneth Kauda Foundation.

Ollendick, T. H., \& King, N. J. (1991). Origins of childhood fears: An evaluation of Rachman's theory of fear acquisition. Behaviour Research and Therapy, 29(2), 117-123. https://doi.org/10.1016/ 0005-7967(91)90039-6

Ollendick, T. H., King, N. J., \& Frary, R. B. (1989). Fears in children and adolescents: Reliability and generalizability across gender, age and nationality. Behaviour Research and Therapy, 27(1), 19-26. https://doi.org/10.1016/0005-7967(89)90115-0

Ollendick, T. H., Yang, B., King, N. J., Dong, Q., \& Akande, A. (1996). Fears in American, Australian, Chinese, and Nigerian children and adolescents: A cross-cultural study. Journal of Child Psychology and Psychiatry, 37(2), 213-220. https://doi.org/10. 1111/j.1469-7610.1996.tb01393.x

Öhman, A. (1986). Face the beast and fear the face: Animal and social fears as prototypes for evolutionary analyses of emotion. Psychophysiology, 23(2), 123-145. https://doi.org/10.1111/j.1469-8986. 1986.tb00608.x

Öhman, A. (2009). Of snakes and faces: An evolutionary perspective on the psychology of fear. Scandinavian Journal of Psychology, 50(6), 543-552. https://doi.org/10.1111/j.1467-9450.2009.00784.x

Packer, C., Swanson, A., Ikanda, D., \& Kushnir, H. (2011). Fear of darkness, the full moon and the nocturnal ecology of African lions. PLoS ONE, 7, e22285. https://doi.org/10.1371/journal. pone. 0022285

Penkunas, M. J., \& Coss, R. G. (2013a). Rapid detection of visually provocative animals by preschool children and adults. Journal of Experimental Child Psychology, 114(4), 527-536. https://doi. org/10.1016/j.jecp.2012.10.001

Penkunas, M. J., \& Coss, R. G. (2013b). A comparison of rural and urban Indian children's visual detection of threatening and nonthreatening animals. Developmental Science, 16(3), 463-475. https://doi.org/10.1111/desc.12043

Penkunas, M. J., Coss, R. G., \& Shultz, S. (2014). Risk assessment by British children and adults. International Journal of Psychological Studies, 6(3), 32-43. https://doi.org/10.5539/ijps.v6n3p32
Poo, M-C. (2006) The concept of ghost in ancient Chinese religion. In J. Lagerwey (Ed.), Religion and Chinese society Vol. 1, Ancient and medieval China (pp. 173-192). Chinese University Press.

Plavcan, J. M., Lockwood, C. A., Kimbel, W. H., Lague, M. R., \& Harmon, E. H. (2005). Sexual dimorphism in Australopithecus afarensis revisited: How strong is the case for a human-like pattern of dimorphism? Journal of Human Evolution, 48(3), 313-320. https://doi.org/10.1016/j.j.hevol.2004.09.006

Poulton, R., \& Menzies, R. G. (2002a). Non-associative fear acquisition: A review of the evidence from retrospective and longitudinal research. Behaviour Research and Therapy, 40(2), 127-149. https://doi.org/10.1016/S0005-7967(01)00045-6

Poulton, R., \& Menzies, R. G. (2002b). Fears born and bred: Toward a more inclusive theory of fear acquisition. Behaviour Research and Therapy, 40(2), 197-208. https://doi.org/10.1016/S00057967(01)00052-3

Purkis, H. M., \& Lipp, O. V. (2007). Automatic attention does not equal automatic fear: Preferential attention without implicit valence. Emotion, 7(2), 314-323. https://doi.org/10.1037/1528-3542.7.2.314

Rachman, S. (1977). The conditioning theory of fear-acquisition: A critical examination. Behaviour Research and Therapy, 15(5), 375-387. https://doi.org/10.1016/0005-7967(77)90041-9

Rachman, S. (2002). Fears born and bred: Non-associative fear acquisition? Behaviour Research and Therapy, 40(2), 121-126. https:// doi.org/10.1016/S0005-7967(01)00044-4

Ramakrishnan, U., \& Coss, R. G. (2000). A comparison of the sleeping behavior of three sympatric primates: A preliminary report. Folia Primatologica, 72, 51-53.

Ramakrishnan, U., \& Coss, R. G. (2001). Strategies used by bonnet macaques (Macaca radiata) to reduce predation risk while sleeping. Primates, 42, 193-206. https://doi.org/10.1007/BF02629636

Reichard, U. (1998). Sleeping sites, sleeping places, and presleep behavior of gibbons (Hylobates lar). American Journal of Primatology, 46, 35-62. https://doi.org/10.1002/(SICI)10982345(1998)46:1\%3c35::AID-AJP4\%3e3.0.CO;2-W

Reno, P. L., Meindl, R. S., McCollum, M. A., \& Lovejoy, C. O. (2003). Sexual dimorphism in Australopithecus afarensis was similar to that of modern humans. Proceedings of the National Academy of Sciences of the USA, 100(16), 9404-9409. https://doi.org/10. 1073/pnas.1133180100

Reno, P. L., \& Lovejoy, C. O. (2015). From Lucy to Kadanuumuu: Balanced analyses of Australopithecus afarensus assemblages confirm only moderate skeletal dimorphism. PeerJ, 3, e925. https://doi.org/10.7717/peerj.925

Rittichainuwat, B. (2011). Ghosts, a travel barrier to tourism recovery. Annals of Tourism Research, 38(2), 437-459. https://doi.org/10. 1016/j.annals.2010.10.001

Rose, R. J., \& Ditto, W. B. (1983). A developmental-genetic analysis of common fears from early adolescence to early adulthood. Child Development, 54(2), 361-368. https://doi.org/10.2307/1129697

Russell, P. A. (1979). Fear-evoking stimuli. In W. Sluckin (Ed.), Fear in animals and man (pp. 86-121). Van Nostrand Reinhold Company.

Rutter, M., \& Garmezy, N. (1983). Developmental psychopathology. In P. H. Mussen (Ed.), Handbook of child psychology (pp. 775911). John Wiley \& Sons.

Sayfan, L., \& Lagattuta, K. H. (2009). Scaring the monster away: What children know about managing fears of real and imaginary creatures. Child Development, 80(6), 1756-1774. https://doi.org/10. 1111/j.1467-8624.2009.01366.x

Scherer, M. W., \& Nakamura, C. Y. (1968). A fear survey schedule for children (FSS-FC): A factor analytic comparison with manifest anxiety (CMAS). Behaviour Research and Therapy, 6(2), 173-182. https://doi.org/10.1016/0005-7967(68)90004-1

Scott, A. O. (2017). Summoning brand-name terror. New York Times Weekend Arts I Film Review, May 19, C3 and C7. 
Scott, J. E., \& Stroik, L. K. (2006). Bootstrap tests of significance and the case for humanlike skeletal-size dimorphism in Australopithecus afarensis. Journal of Human Evolution, 51(4), 422-428. https://doi.org/10.1016/j.jhevol.2006.06.001

Seligman, M. E. P. (1970). On the generality of the laws of learning. Psychological Review, 77(5), 406-418. https://doi.org/10.1037/ h0029790

Seligman, M. E. P. (1971). Phobias and preparedness. Behavior Therapy, 2(3), 307-320. https://doi.org/10.1016/S0005-7894(71) 80064-3

Shariff, A. F., \& Norenzayan, A. (2007). God is watching you, priming God concepts increases prosocial behavior in an anonymous economic game. Psychological Science, 18(9), 803-809. https:// doi.org/10.1111/j.1467-9280.2007.01983.x

Sidana, U. R. (1975). Socio-economic status of family and fear in children. Journal of Social and Economic Studies, 3, 89-99.

Silverman, I., \& Eals, M. (1992). Sex differences in spatial abilities: Evolutionary theory and data. In J. H. Barkow, L. Cosmides, \& J. Tooby (Eds.), The adapted mind: Evolutionary psychology and the generation of culture (pp. 533-549). Oxford University Press.

Silverman, I., Choi, J., \& Peters, M. (2007). The hunter-gatherer theory of sex differences in spatial abilities: Data from 40 countries. Archives of Sexual Behavior, 36(2), 261-268. https://doi.org/10. 1007/s10508-006-9168-6

Skre, I., Onstad, S., Torgensen, S., Lygren, S., \& Kringlen, E. (2000). The heritability of common phobic fear: A twin study of a clinical sample. Journal of Anxiety Disorders, 14(6), 549-562. https://doi.org/10.1016/S0887-6185(00)00049-9

Spörrle, M., \& Stich, J. (2010). Sleeping in safe places: An experimental investigation of human sleeping place preferences from an evolutionary perspective. Evolutionary Psychology, 8(3), 405-419. https://doi.org/10.1177/147470491000800308

Stevenson, J., Batten, N., \& Cherner, M. (1992). Fears and fearfulness in children and adolescents: A genetic analysis of twin data. Journal of Child Psychology and Psychiatry, 33(6), 977-985. https://doi.org/10.1111/j.1469-7610.1992.tb00919.x

Suedfeld, P., \& Mocellin, J. S. P. (1987). The "sensed presence" in unusual environments. Environment and Behavior, 19(1), 33-52. https://doi.org/10.1177/0013916587191002

Susman, R. L., Stern, J. T., Jr., \& Jungers, W. L. (1984). Arboreality and bipedality in the Hadar hominids. Folia Primatologica, 43(2-3), 113-156. https://doi.org/10.1159/000156176

Testa, M., \& Debû, B. (1997). Analyse tridimensionnelle des variations de forces associées à une tâche d'escalade chez des adolescents. [Three-dimensional analysis of the force variations associated with a climbing task in adolescents]. Archives of Physiology and Biochemistry, 105(5), 496-506. https://doi.org/10.1076/apab. 105.5.496.3290

Thinh, N. D. (2006). The mother goddess religion: its history, pantheon, and practices. In K. Fjelstad \& N. T. Hien (Eds.), Possessed by the spirits: Mediumship in contemporary Vietnamese communities (pp. 19-30). Ithaca, New York: Southeast Asia Program Series 23, Cornell University Press.

Tobacyk, J., \& Milford, G. (1983). Belief in paranormal phenomena: Assessment instrument development and implications for personality functioning. Journal of Personality and Social Psychology, 44(5), 1029-1037. https://doi.org/10.1037/0022-3514.44.5.1029

Torgersen, S. (1979). The nature and origin of common phobic fears. British Journal of Psychiatry, 134(4), 343-351. https://doi.org/ 10.1192/bjp.134.4.343

Treves, A., \& Naughton-Treves, L. (1999). Risk and opportunity for humans coexisting with large carnivores. Journal of Human Evolution, 36(3), 275-282. https://doi.org/10.1006/jhev.1998.0268

Tucker, M., \& Bond, N. W. (1997). The roles of gender, sex role, and disgust in fear of animals. Personality and Individual Differences, 22(1), 135-138. https://doi.org/10.1016/S0191-8869(96) 00168-7

Villmoare, B., Hatala, K. G., \& Jungers, W. (2019). Sexual dimorphism in Homo erectus inferred from 1.5 Ma footprints near Ileret, Kenya. Scientific Reports, 9, 7687. https://doi.org/10.1038/ s41598-019-44060-2

Villmoare, B., Kimbel, W. H., Seyoum, C., Campisano, C. J., DiMaggio, E. N., Rowan, J., \& Reed. K. E. (2015). Early Homo at 2.8 Ma from Ledi-Geraru, Afar, Ethiopia. Science, 347(6228), 1352-1354. https://doi.org/10.1126/science.aaa1343

Williams, G. C. (1966). Adaptation and natural selection: A critique of some current evolutionary thought. Princeton University Press.

Wilson, W., \& Miller, H. L. (1968). Fear, anxiety, and religiousness. Journal for the Scientific Study of Religion, 7(1), 111. https://doi. org/10.2307/1385119

Wirtz, P., \& Wawra, M. (1986). Vigilance and group size in Homo sapiens. Ethology, 71(4), 283-286. https://doi.org/10.1111/j. 1439-0310.1986.tb00592.x

Yorzinski, J. L., Penkunas, M. J., Platt, M. L., \& Coss, R. G. (2014). Dangerous animals capture and maintain attention in humans. Evolutionary Psychology, 12(3), 534-548. https://doi.org/10. $1177 / 147470491401200304$

Publisher's Note Springer Nature remains neutral with regard to jurisdictional claims in published maps and institutional affiliations. 